\title{
DATA ENVELOPMENT ANALYSIS (DEA) EFFICIENCY OF ISLAMIC BANKS IN ASEAN: A CROSS-COUNTRY COMPARATIVE EXAMINATION OF INTERMEDIATION AND PRODUCTION EFFICIENCY APROACH
}

\section{Taufik Faturohman, Auryn Khansa Maharani, Oktofa Yudha Sudrajad, Atika Irawan} Institut Teknologi Bandung

\author{
A R T I C L E I N F O
}

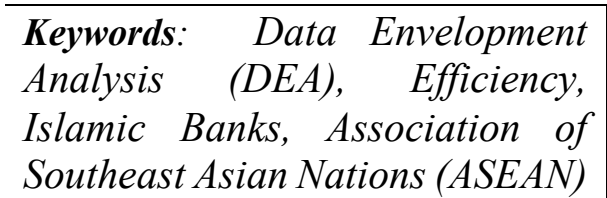

Kata Kunci: Data Envelopment Analysis (DEA), Efisiensi, Bank Syariah, ASEAN

Corresponding author:

Taufik Faturohman taufik.f@sbm-itb.ac.id
Abstract: In 2015 ASEAN leaders agreed to form an integrated market called ASEAN Economic Community (AEC) that enables countries in Southeast Asia to trade goods and services more easily, attracting strong demand from investors and heightened the competition in the industry. The heightened of competition should encourage banks to reduce operating costs and, hence, eliminate inefficiencies in the banking industry. The objective of this study is to examine the relative efficiency scores of Islamic banks across six countries in ASEAN from 2011 to 2018. The study implement Data Envelopment Analysis under the intermediation and production approach. Despite the rapid growth of the Islamic banking, examination of Islamic banks at a cross-country level is still at its infancy, especially in ASEAN. Therefore, this research aims to fill the gap in the literature by providing the empirical evidence on the efficiency of Islamic banks in ASEAN during 2011-2018. The analysis is divided into two frontiers, namely single-multiyear frontier to examine the efficiency trends of all ASEAN countries in eight years and cross-sectional frontier to compare the efficiency of countries in ASEAN per year. The single multi-year frontier shows that the Philippines, Malaysia, Thailand and Singapore presents positive trend efficiency, while Indonesia fell, and Brunei fluctuated. Cross-sectional frontier shows that Brunei is the country that is most frequent in achieving optimum efficiency. Furthermore, the higher the efficiency of an Islamic banking industry, the more it's contributes to society and the economy as a whole

Abstrak: Pada tahun 2015 para pemimpin ASEAN sepakat untuk membentuk pasar terpadu yang disebut Masyarakat Ekonomi ASEAN (MEA) yang memungkinkan negara-negara di Asia Tenggara untuk berdagang barang dan jasa dengan lebih mudah, menarik permintaan kuat dari investor dan meningkatkan persaingan di negara-negara tersebut. industri. Tingginya kompetisi mendorong bank untuk mengurangi biaya operasional dan, karenanya, menghilangkan inefisiensi dalam industri perbankan. Tujuan dari penelitian ini adalah untuk menguji skor efisiensi relatif bank-bank Islam di enam negara di ASEAN dari 2011 hingga 2018. Studi ini mengimplementasikan Analisis Envelopment Data di bawah pendekatan intermediasi dan produksi. Meskipun pertumbuhan perbankan syariah cepat, pemeriksaan bank-bank Islam di tingkat lintas negara masih dalam masa pertumbuhan, terutama di ASEAN. Oleh karena itu, penelitian ini bertujuan untuk mengisi kesenjangan dalam literatur dengan memberikan bukti empiris pada efisiensi bank syariah di ASEAN selama 2011-2018. Analisis ini dibagi menjadi dua perbatasan, yaitu perbatasan tunggal-multi-tahun untuk menguji tren efisiensi semua negara ASEAN dalam delapan tahun dan perbatasan lintas bagian untuk membandingkan efisiensi negara-negara di ASEAN per tahun. Perbatasan tunggal multi-tahun menunjukkan bahwa Filipina, Malaysia, Thailand, dan Singapura menghadirkan efisiensi dengan tren positif, sementara Indonesia menurun, dan Brunei berfluktuasi. Perbatasan cross-sectional menunjukkan bahwa Brunei adalah negara yang paling sering mencapai efisiensi optimal. Selain itu, semakin tinggi efisiensi industri bank syariah, semakin memberikan kontribusi kepada masyarakat dan ekonomi secara keseluruhan 


\section{INTRODUCTION}

Islamic banks have been a phenomenon as one of the fastest growing financial sectors. Starting in 1963 in Egypt, the world's first Islamic bank was born with the name Mit Ghamr Local Savings Bank of Egypt. Since then, Islamic banks started to grow rapidly. In the 1980s the Middle East country had a large growth in surplus funds and Muslim investment has spread throughout the world (Bt Ahmad, Mohamad, \& Sufian, 2010)

In 2017, the number of Islamic banks in the world has increased by more than 500 units in more than 75 countries worldwide (Research and Markets, 2019). It is mainly concentrated in the Middle East and Southeast Asia. In Southeast Asia alone, there are 35 data available of Islamic banks across six countries including Indonesia, Malaysia, Singapore, Thailand, Brunei, and Philippines that hold vital segment in financial markets. These countries aim to use the most comprehensive and advanced version of Islamic banking to attract Islamic business and investment from around the globe.

In 2015 ASEAN (Association of Southeast Asian Nations) leaders agreed to form an integrated market called ASEAN Economic Community (AEC) that enables countries Southeast Asia countries to trade goods and services more easily (BBC Indonesia, 2014), attracting strong demand from investors and heightened the competition in the industry. The heightened of competition should encourage banks to reduce operating costs and, hence, eliminate inefficiencies in the banking industry (Turan, 2015). Arrawatia, Misra, \& Dawar (2014) also found that competition positively effects efficiency and vice-versa. Then it needs to be examined whether the Islamic bank in ASEAN is efficient enough to face the tightening competition.

Despite the rapid growth of the Islamic banking, examination of Islamic banks at a cross-country level is still at its infancy, especially in ASEAN. Therefore, this research aims to fill the gap in the literature by providing the empirical evidence on the efficiency of Islamic banks in ASEAN during 2011-2018. Furthermore, the information on efficiency will enable policy-makers to formulate policies to direct their banking industry to be more efficient.

\section{Islamic Banks}

\section{LITERATURE REVIEW}

Islamic banks were originally present to meet the needs of Muslims for financial devices that use Islamic principles. To be consistent with the principles of Islamic law and guided by Islamic economics, Islamic banking and finance prohibits a variety of activities:

1. Paying or charging interest.

2. Investing in haraam business activites.

3. Charging extra for late payment.

4. Involving in contract where the ownership of a good depends on the occurrence of a predetermined, uncertain event in the future. This is called maisir

5. Gharar, usually translated as ambigutity and uncertainty. Tends to rule out derivatives, options and future.

6. Engaging in transaction that is not linked with real underlying economic transaction.

In its efforts to replace the interest system, Islamic banks use risk-based investment functions. Leading to sustainable economic growth and fair opportunities for all, Islamic banks guarantee an optimal level of capital formulation and efficient use (Bhatti \& Khan, 2008). The three boards of Islamic banking function are as follow:

1. Profit and loss sharing where the contracts are based on partnership.

2. Trade-based financing which has similar method to conventional banking, it's just that the fixed return is called "profit" not "interest". This instrument includes murabaha, leasing, cash advances for agricultural products, and for the manufacturing.

3. Contracts of safety and security

\section{Efficiency}

Mathematically, efficiency means the calculation of the ratio of output and input. There are several concept in efficiency, the most common concept is technical efficiency: the conversion of physical inputs into outputs. In maximum technical efficiency, it is interpreted that given current technology, there will be no wastage of inputs in producing the given quantity of output (Bhagavath, 2006).

Allocative efficiency refers to whether inputs, for a given level of output and set of input prices, are chosen to minimize the cost of production, assuming that the firm being examined is already fully technically efficient (Bhagavath, 2006). 
Allocative efficiency is also expressed as a score ranging from 0 to 1 , a maximum score of 1 indicating that the organization is using its inputs in the proportion that would minimize costs.

Finally, economic efficiency refers to the combination of technical and allocative efficiency. An organization will only be economic efficient if it is both technically and allocatively efficient (Bhagavath, 2006). economic efficiency is calculated as the product of the technical and allocative efficiency scores. Hence, an organization can only achieve a maximum score in economic efficiency if it has achieved maximum in both technical and allocative efficiency.

\section{Methods to Measure Efficiency}

There are various method in measuring efficiency that categorized in two approaches; parametric and non-parametric. Stochastic Frontier Analysis (SFA) and Deterministic Frontier Analysis (DFA) are two parametric approaches that have been commonly used to measure x-efficiency in banks and financial institution (Rahman, 2011). Such as studies that were conducted by Hassan (2003 and 2006), Allen and Rai (1995) they measured operational efficiency in banking internationally during 1988-1992 using SFA and DFA, while (Hadad et al., 2003) used SFA and DFA methods to measure the efficiency of banks in Indonesia during 1995-2003. Meanwhile, Hasan (2003) measured the efficiency of Islamic banks in Pakistan, Iran, and Sudan during 1994-2001 using SFA (cost and profit efficiencies), and DEA (cost, allocative, technical, pure technical, and scale efficiencies).

DEA method, as a non-parametric approach has been extensively used in many research. Rahman (2011) found that some of those researches that measure efficiency of Islamic banks using DEA Application are conducted by Yudistira (2003), Ascarya and Yumanita (2006, 2007a, and 2007b), Sufian (2006) and Zamil and Rahman (2007). Yudistira measured the efficiency of 18 Islamic banks from various countries during 1997 - 2000 using intermediation approach. Ascarya and Yumanita (2006) measured the efficiency of Islamic banks in Indonesia during $2002-2004$ using intermediation and production approaches, since the dualism of banks that are not only viewed as intermediaries institution, but also as production entity. Sufian (2006) measured the efficiency of Islamic window in Malaysia during 2001-2004 using intermediation approach with the same reason as that of Yudistira. Mochtar et al. (2007) measured the efficiency of 22 Islamic banks (20 windows and 2 full- fledged) and 20 conventional banks in Malaysia during 1997-200. Meanwhile, Zamil and Rahman (2007) measured the efficiency of Islamic banks and conventional banks in Malaysia during 2001-2004 using intermediation approach.

Of the approaches, the main attraction of parametric approach is that they allow hypothesis testing and the construction of confidence intervals. However, the drawbacks are the need to assume a functional form for the frontier technology and for the distribution of the technical inefficiency term (Rahman, 2011). Amongst the parametric approaches some are SFA, and so attempt to distinguish the effects of uncontrollable error, such as adverse weather conditions, supply shocks and measurement error from specific sources of inefficiency, while a non-stochastic approach lumps noise and inefficiency together and arranges the combination of inefficiency (Rahman, 2011).

In non-parametric approach, such assumption is unnecessary, i.e., the non-parametric approach is less prone to these types of specification error. But the major weakness of the non-parametric approach is that it is deterministic, and cannot decompose the unknown effects or unknown errors. The non-parametric approach assumes that the error term, and any level of deviations are attributed to inefficiency.

These features imply that each of these methods has advantages and disadvantages and there is no obviously superior approach. Therefore, the selection between these approaches depends upon the objective of the study, the type of bank and the data available.

\section{Data Envelopment Analysis}

Data Envelopment Analysis (DEA) is an efficiency measurement approach that is included in the non-parametric approach. It measures the relative technical efficiency of decision making units (DMU). DEA identifies the best practice amongst DMU using linear programming technique. This approach was proposed by Charnes (1978) and extended by banker, Charnes and Cooper (1984). The work of Charnes et al.is actually based on Farrel's work that measure technical efficiency using multiple input and output. Farrell's technique plots an efficiency frontier or group of best performer as depicted in Figure 1. 


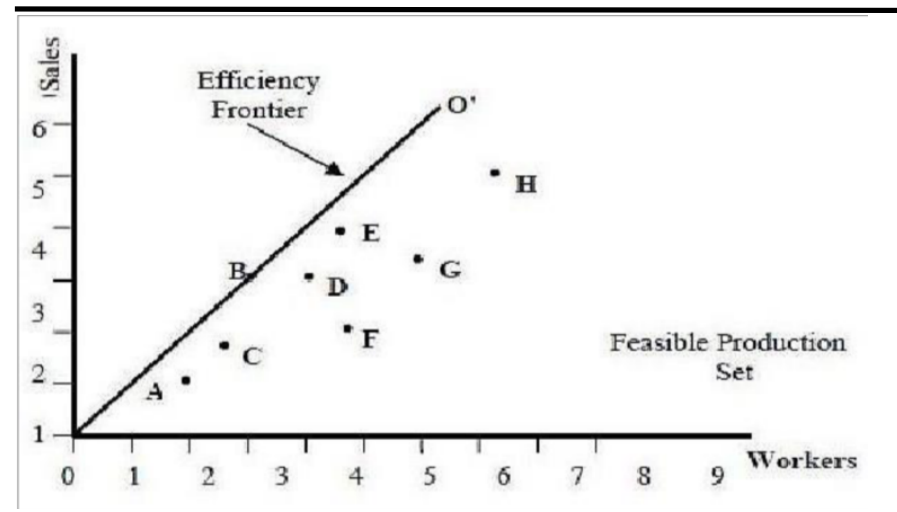

Figure 1: Efficiency Frontier and Feasible Production Set

Source: Pandey, Satapathy, 2014

It shows that B is the most efficient DMU. Line OO' that passes point B represents the efficiency frontier. All the points below OO' are said to be inefficient and expressed as a percentage of B. Thus, OO' "envelopes" the rest of the points in Figure 1.

There are types of orientation and scale in DEA approach that will be explained in sub chapter below.

\section{Scale Efficiency (SE)}

It is possible that a firm is technically and allocatively efficient but has not reach the optimum scale of operation. If the underlying production technology is a globally constant-return-to-scale (CRS), then the firm is automatically scale efficient (Coelli, O'Donnell, Rao, \& Battese, 1998). The CRS assumption is appropriate when all firms are operating at an optimal scale. However, many factor such as imperfect competition and government regulation may cause the firms to work at unoptimum scale. Suppose the firm involved may be too small in its scale of operation, which might fall within the increasing-return-to-scale and also might fall within decreasing-return-to-scale if the firm is too large, the firm should use a variable-return-to-scale (VRS).

\section{Input and Output Orientation}

Figure 2 shows Farrel's input-oriented measure of technical efficiency where the company uses two inputs of X1 and $\mathrm{X} 2$ to produce one output Q. If the company produces along QQ', then it is technically efficient. Every point in line $\mathrm{D}$ that falls above point $\mathrm{C}$ is considered technically inefficient. The point $\mathrm{CD}$ represents the amount of how much the inputs must be reduced measured by the ratio $\mathrm{CD} / \mathrm{OD}$. In other words $\mathrm{TE}=1-\mathrm{CD} / \mathrm{OD}$, thus it must lie somewhere between $0-1$. Assume that the price of $\mathrm{X} 1$ and $\mathrm{X} 2$ are fixed, then the distributed efficiency is represented by the ratio of $\mathrm{OB} / \mathrm{OC}$, and the distance $\mathrm{BC}$ is the amount by which the cost must be reduced to produce at $\mathrm{P}$ '.

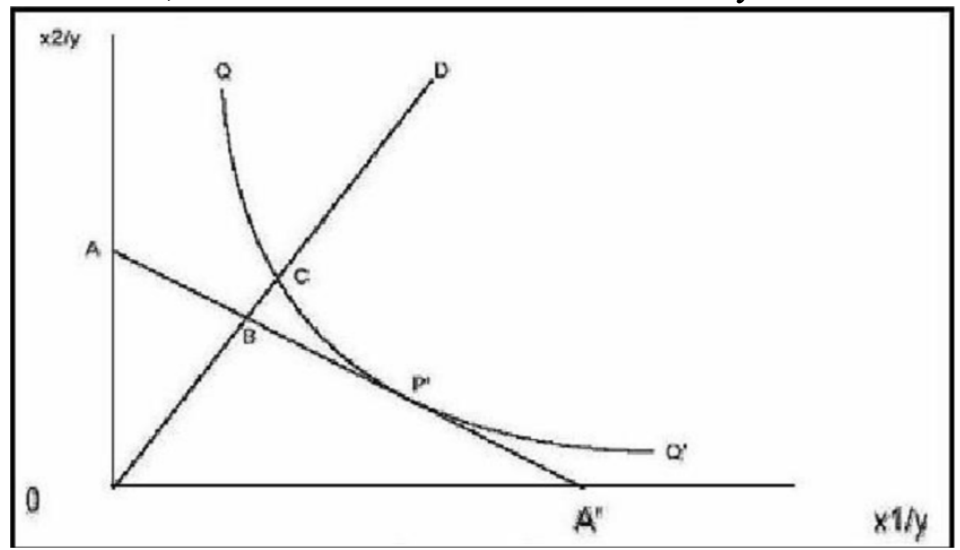

Figure 2: Input-oriented Technical Efficiency

Source: Pandey, Satapathy, 2014

Furthermore, Figure 3 shows Farrel's output-oriented measure of technical efficiency where the company uses one input X1 to produce two outputs Q1 and Q2. The company Is said to be technically efficient if all the points fall below 
PP' that denotes the production frontier. The distance AB shows the measure of technical efficiency or the amount by which outputs may be increased with certain level of input.

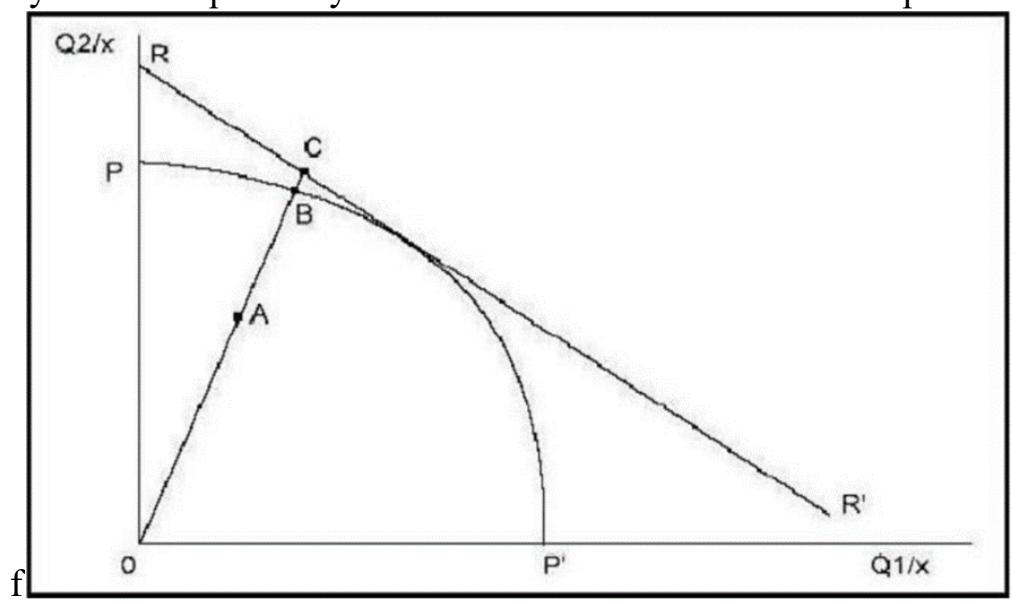

Figure 3: Output-oriented Technical Efficiency

Source: Pandey, Satapathy, 2014

\section{Approaches to Measure Bank Efficiency}

There are many approaches in measuring bank efficiency, namely asset approach, intermediation approach, and production approach. Generally, previous studies viewed banks from two main perspectives. The approaches are the intermediation and the production approach (Akhtar, 2010; Mohamad, Hassan, \& Bader, 2008; Sufian, 2007b; Sufian \& Haron, 2009).

The production approach on the other hand explains banking activities as production of services. This approach defines banks as manufacturer of loan to borrowers and deposit operators to depositors using capital and labour. However, the production approach is said to be predominantly suitable for banks that involves in transaction of channelling the bulky deposits and money obtained from other financial organizations into loans and investments (Favero \& Papi, 1995). Moreover, interest expenses is not inclusive in the summation of total costs under the production approach, thus only operating costs are considered and output is determined by the number of accounts serviced rather than monetary values (Hassan, Mohamad, \& Bader, 2009).

The intermediation approach defines banks to be seen as a mediator of monetary transactions. As was recommended by (Sealey \& Lindley, 1977) this approach presents a bank as an intermediary that takes deposits from customers using labour and capital. These deposits are considered as inputs to the banks and are lent out to other customers that want to borrow money in form of loans and advances which are considered as output to the banks. Intermediation approach is arguably, the most globally accepted approach used to measure bank efficiency (Kwan, 2003). Berger \& Humphrey (1997) opined that this is because it includes interest expenses (interest paid to depositors). The interest expenses, often amounted to the half of the total costs of the banking operating expenses (Hassan, Mohamad, \& Bader, 2009)

The intermediation approach is adopted by this study based on the following grounds: First, this study is assessing the whole banks efficiency. Secondly, the intermediation approach is widely adopted (Kwan 2003). Finally, the Islamic finance structure principle is based on profit sharing and asset-based financing where the parties involved in the transaction bear the losses or profits based on agreed ratio. These principles show importance of intermediary activities. Also other studies such as Hassan \& Hussein (2003), Hasan (2005) and Sufian (2006) just to mention but a few have also used this approach to measure Islamic banking efficiency. This study also use the production approach because although some studies mentioned that production approach is more suitable to measure bank's branches efficiency, reason been that at branch level customer documents are managed for the banks as a whole (Kwan, 2003).

\section{Previous Study}

Mokhtar, Abdullah, and Alhabshi (2008) compared the efficiency of two fully fledged Islamic banks, twenty Islamic windows, and twenty non-Islamic banks in Malaysia during 1997-2003. They measured technical and cost efficiency by applying DEA with an intermediation approach, using total deposits and total overhead expenses as input variables. 
Total earning assets were used as output variables. They found that the efficiency of Islamic banks increased from 1997 to 2003, and that fully fledged Islamic banks were more efficient than Islamic windows, but less efficient than non-Islamic banks

Arrawatria, Misra, \& Dawar (2014) investigate the relationship between competition and effciency. Using bank-level data for Indian banks, relationship between competition. Efficiency was examined using DEA, intermediation approach by employing operating expense, interest expense as input to produce deposits, interest income, and feebased income. The finding was the competition positively effects efficiency and vice-versa.

Y. Altunbas, E.P.M. Gardener, \& P. Molyneux (2001) Found that Europe's largest banks benefit most from technical progress although they do not appear to have scale economy advantages over their smaller counterparts . Efficiency was examined by applying stochastic cost frontier with intermediation approach. Examining 15 European banks from 1989-1997. The inputs are labor, physical capital and deposits, the output are total earning asset, total loans, total off-balance sheet.

Ferreira (2013) applied an intermediation DEA to measure the efficiency. Using borrowed funds, physical capital and labour as inputs and total loans, total securities and other earning assets as outputs. The results suggest that within this panel of all $27 \mathrm{EU}$ countries over a relatively long time period, from 1996 to the onset of the 2008 financial crisis, the more cost-efficient commercial and savings banks operated in less concentrated markets.

Sufian, Fadzlan, A.M Noor, \& Muhamed-Zul (2009) compared the efficiency of islamic 37 Islamic banks in16 countries in the MENA region and in Asia during 2001-2006 by applying DEA using total deposits and physical capital as inputs and total loans, income, and investments as outputs. They found that the MENA Islamic banks showed a higher technical efficiency than Asian Islamic banks.

Ascarya, Yumanita, Noer A. Achsani, \& Gur (2010) Measured the Efficiency of Islamic Banks in Indonesia and Malaysia in the period of 2002-2006 using Parametric and Nonparametric Approaches assuming that Islamic banks produce Total loans and total income by employing total deposits, labor, and fixed assets. The finding was that the average efficiency scores of the Indonesian Islamic banks were higher than those of the Malaysian banks.

Bt Ahmad, Mohamad, \& Sufian (2010) investigates the efficiency of the Islamic banking sectors in the world covering 25 countries during the period of 2003-2009. The efficiency estimates of individual banks are evaluated using DEA. The findings suggest that during the period of study, pure technical efficiency outweighs scale efficiency in World Islamic banking countries. Islamic banks are modelled as multi-product firms producing three outputs namely, total deposits, labour cost, and total assets which include total deposits, labour cost, and total assets as input. They found that the average efficiency of Islamic banks improved during the global financial crisis.

Said (2013) examined the correlation between risks and efficiency within Islamic banks in the MENA area for the period of 2006-2009 by applying the DEA with intermediation approach for efficiency, using fixed asset, deposits, labor cost as inputs to produce total loans, liquid assets, and other income. The result shows that credit and operational risks were negatively correlated with efficiency levels.

\section{Data Collection Method}

\section{METHODOLOGY}

This research uses secondary data. The data is obtained from BankFocus. The period of data used is from 2011 to 2018 to capture the difference of the efficiency. This research is using all kind of Islamic bank in ASEAN. The data used for this research is an unbalanced panel of 34 banks in eight years observation, resulting in 236 observations. Maybank Islamic Berhad is excluded because the data of fixed assets are unavailable. Data for the empirical analysis is sourced from individual bank's annual financial statements. The BankFocus database converts the data to common international standards to facilitate comparisons and all financial information is reported in local currency. This study converts the local currency data into USD using year-end currency exchange rates which makes the comparison across country consistent.

This study measures the technical efficiency with output-oriented and with the VRS. The object observed are ASEAN countries including non-Muslim majority countries such as Thailand, Singapore, and the Philippines. Despite of their differences in religion background, the non-Muslim countries are still relevant to be included. This assumption is based on the findings of Christanti, Wulandari, Narmaditya, \& Utomo (2017). They found that religious motive does not affect the use of Islamic banking services they conducted quantitative research (questionnaires). This research shows that rationale advantages factors such as administrative costs is cheaper compared to conventional banking which incur interest, as well as other factors such as family support and for the work. Beside conducting qualitative 
research, they also conducted qualitative research (in-depth interview). Through this method they also found that religious aspect doesn't affect the use of Islamic banks service either to Muslim nor non-Muslim customers in Klojen, Malang. Their research is limited in Malang, Indonesia. because ASEAN countries are located in the same region, despite the differences, this research assumes that such results also prevail in the other ASEAN countries. Thus, this research includes non-Muslim ASEAN countries such as Thailand, Singapore, and the Philippines.

\section{Data Description}

The data needed for this empirical analysis comes from financial statements of Islamic banks in ASEAN in the period of 2011-2018. The list of countries and Islamic banks included with its year available in this study can be read in Table 1.

Table 1: Number of Islamic Banks

\begin{tabular}{|c|c|c|c|c|c|c|c|c|}
\hline \multirow[t]{2}{*}{ Country } & \multicolumn{8}{|c|}{ Number of bank } \\
\hline & 2011 & 2012 & 2013 & 2014 & 2015 & 2016 & 2017 & 2018 \\
\hline Brunei & 1 & 1 & 1 & 1 & 1 & 1 & 1 & 1 \\
\hline Indonesia & 9 & 10 & 11 & 11 & 11 & 11 & 7 & 6 \\
\hline Malaysia & 18 & 18 & 18 & 18 & 18 & 18 & 17 & 13 \\
\hline Philippines & - & - & 1 & 1 & 1 & 1 & 1 & 1 \\
\hline Singapore & - & - & 1 & 1 & 1 & - & - & - \\
\hline Thailand & - & - & 1 & 1 & 1 & 1 & 1 & - \\
\hline
\end{tabular}

\section{Data Envelopment Analysis (DEA)}

The non-parametric approach that will be used in this study is DEA. The purpose of using DEA in this study is to measure the relative efficiency of several Islamic banks by aggregating multiple performance indicators into a single framework for identifying best practice. The following is a DEA advantage (Karimah, 2016):

1. Does not require pre-specifications on the function.

2. More flexible in its ability to include a lot of output and output in estimating efficiency (Suzuki \& Sastrosuwito, 2012).

3. Quite reliable for small samples.

DEA efficiency scores range from 0 to 1 , the closer to 1 , the more efficient the bank's performance relative to the peer in the frontier. DEA will compute the value of $h_{s}$ that denotes the relative efficiency score of the Islamic bank.

Where:

$$
h_{s}=\frac{\sum_{i=1}^{m} U_{i s} Y_{i s}}{\sum_{j=1}^{n} V_{j s} X_{j s}}
$$

$h_{s}$ : technical efficiency of bank s;

Uis: weight of output

Yis: the number of $\mathrm{i}$ output 1 produced

$X j s$ : number of $\mathrm{j}$ input used by bank $\mathrm{s}$;

The problem that appears in Equation 1 is the emergence of a solution that is not limited to time so that the efficiency score between $0-1$ does not materialize. To avoid this, the following constraint functions are formulated;

$$
\frac{\sum_{i=1}^{m} U i s Y i s}{\sum_{j=1}^{n} \operatorname{VjS} X j s} \leq 1 ; r=1,2, \ldots, N \text { and } U i, Y j \geq 0 \ldots
$$

where $\mathrm{N}$ indicates the number of banks in the sample. Equation (2) shows that the efficiency score is positive with a value between 0 and 1 . At DEA, each bank can determine its respective weighting and ensure that the selected weight will produce the best performance measure (Firdaus \& Hosen, 2013). The transformation of equations (1) and (2) is finally called the DEA CRS model.

The DEA CRS model compares all individuals in the sample assuming that the internal and external conditions of the DMU are the same or that individual conditions operate optimally. DEA CRS states that an increase in the number of bank inputs by $5 \%$ will result in an increase in the amount of output by $5 \%$. DEA maximizes the summation of multiplication between the weight of output $i$ with the number of outputs $i$ in the Islamic banking period $s$.

The following are the equations in the DEA CRS model: 


$$
\max h s=\sum_{i=1}^{m} u_{i} y_{i s}
$$

When maximizing $h s$ efficiency on condition that;

$$
\begin{aligned}
& \sum_{i=1}^{m} u_{i s} y_{i s}-\sum_{j=1}^{n} v_{j s} x_{j s} \leq 0 \quad{ }^{n} \quad ; \mathrm{r}=1, \ldots, \mathrm{N} \ldots \\
& \sum_{j=1}^{n} v_{j s} x_{j s}=1 ; u_{j}, v_{j} \geq 0
\end{aligned}
$$

The second model is a variable return to scale (VRS) model or commonly called the BCC (Bankers-Charnes-Cooper) model. The VRS model assumes that the internal and external conditions of the DMU are not the same or not all individuals operate optimally, some of which are imperfect competition, financial constraints and so on. Suppose an increase in the number of inputs by 5\% does not result in an increase in the number of outputs of $5 \%$ but is greater or smaller. The mathematical models with the VRS approach are as follows:

Subject to $\sum_{i=1}^{m} u_{i s} y_{i s}-\sum_{j=1}^{n} v_{j s} x_{j s} \leq 0$

$$
\max h s=\sum_{i=1}^{m} u_{i} y_{i s}+U_{0}
$$

Where $\sum_{j=1}^{n} v_{j s} x_{j s}=1$

$$
; \mathrm{r}=1, \ldots, \mathrm{N} \ldots
$$

Where $u_{j}, v_{j} \geq 0$

The concern with DEA model is by choice of weights a high proportion of units will be considered efficient, thus DEA will have little discriminatory power. The first thing to note is that a unit that has the highest ratio of one of the outputs to one of the inputs will be efficient, very close to one by putting as much weight as possible on that ratio and the minimum weight zero on the other inputs and outputs. Since DEA attempts to measure efficiency relative to best practice, the score can't be compared between two studies. DEA also require the number of units being examined to double the total number of variables.

\section{Application of DEA}

This study measure the technical efficiency with output-oriented and with the VRS scale. The object observed are Islamic banks in ASEAN countries including non-Muslim majority countries such as Thailand, Singapore, and the Philippines. Intermediation approach and production approach are adopted to better capture Islamic bank efficiency in its dual role. Intermediation approach is focused on intermediation function on channelling deposits to financing activities in the form of loan to customer $\left(\mathrm{y}_{1}\right)$, and operating income other than interest $\left(\mathrm{y}_{2}\right)$ by employing customer deposits $\left(\mathrm{x}_{1}\right)$, staff expenses $\left(\mathrm{x}_{2}\right)$, and fixed asset $\left(\mathrm{x}_{3}\right)$. In the production approach, the Islamic banks are modelled as multi-product firm which produce three outputs namely, loans to customer (y1), operating income other than interest (y2), and customer deposits (y3), by engaging two inputs namely, staff expenses (X2) and total assets (x3). The input and output can be seen in Table 2:

Table 2: List of Selected Inputs and Outputs

\begin{tabular}{|l|l|l|l|l|}
\hline No & Intermediation & Production \\
\cline { 2 - 5 } & Input (x) & Output (y) to & Input (x) & Staff expenses \\
\hline 1 & Customer deposits & $\begin{array}{l}\text { Loans } \\
\text { customer }\end{array}$ & $\begin{array}{l}\text { Operating } \\
\text { income other } \\
\text { than interest }\end{array}$ \\
\hline 2 & Staff expenses & $\begin{array}{l}\text { Operating income } \\
\text { other than interest }\end{array}$ & Fixed assets & $\begin{array}{l}\text { Customer } \\
\text { deposits }\end{array}$ \\
\hline 3 & Fixed assets & & & $\begin{array}{l}\text { Loan to } \\
\text { customer }\end{array}$ \\
\hline
\end{tabular}


- Deposits and loan are taken from customer only because the main business of the banks is for the customer

- Operating income other than interest comprises total operating income subtracted by interest income

- Interest income is excluded from operating income because it has been represented in loan and deposits

- Interest income is the margin income resulting from the profit/loss sharing resulting from the mark-up of Islamic banks as equivalent to the interest income of non-Islamic Banks (Faturohman, 2013).

\section{DEA Frontier}

Because the value of efficiency produced by DEA is a value relative to the peer, two frontier types are made, a multiyear single run frontier from 2011-2018 to catch the efficiency trend analysis of a country relative to other countries in ASEAN. cross-sectional DEA is conducted annually consisting all countries in ASEAN to compare cross-country relative efficiency in one year.

\section{Treatment to Data With Zero and Negative Numbers}

In the data obtained there are zero and negative numbers that cannot be processed in the DEA, therefore special treatment is needed to overcome them. For example, CIMB Malaysia shows a negative number in operating income other than interest from 2011-2018. The step taken is to add all the numbers with the highest negative number in the series making the lowest value to 0 . After that 0 is replaced by 0.1 as done by Hadad, Hall, Kenjegalieva, Santoso, \& Simper, 2009, alternative ways to deal with negative data in construction of the non-parametric DEA frontier are: to transform (i.e., 'translate') the data, adding a sufficiently large scalar to the data (Ali and Seiford, 1990; Pastor, 1996); to treat absolute negative inputs or outputs as output or input respectively (Scheel, 2001).

\section{Analysis}

From the data gathered, Islamic banks in the Philippines and Singapore have the smallest total fixed assets, while the largest are Brunei followed by Indonesia, Thailand, and Malaysia. Total fixed assets are used as a measure of the size of banks in the country. The order of average customer deposits from the largest to the smallest is Malaysia, Brunei, Thailand, Indonesia, Philippines, and Singapore. Brunei, Thailand, Malaysia, are the three countries which its Islamic banks has the biggest average of staff expenses followed by Indonesia, Singapore, and Philippines. Brunei, Indonesia, Malaysia, Singapore, Philippines, Thailand Islamic banks respectively are countries with the highest to the lowest average of operating income other than interest. Malaysia, Brunei, Thailand, Indonesia, Singapore, Philippines Islamic banks respectively has the highest to the lowest average loans to customer.

Table 3: Average Data Summary (in USD thousands)

\begin{tabular}{|c|c|c|c|c|c|}
\hline Year & $\begin{array}{l}\text { Average Loans } \\
\text { to Customer }\end{array}$ & $\begin{array}{l}\text { Average } \\
\text { (Operating } \\
\text { income-Interest } \\
\text { income) }\end{array}$ & $\begin{array}{l}\text { Average } \\
\text { Staff } \\
\text { Expenses }\end{array}$ & $\begin{array}{l}\text { Average } \\
\text { Customer } \\
\text { Deposits }\end{array}$ & $\begin{array}{l}\text { Average Fixed } \\
\text { Assets }\end{array}$ \\
\hline \multicolumn{6}{|c|}{ Brunei } \\
\hline 2011 & $1,688,941$ & 388,484 & 31,481 & $3,658,574$ & 52,652 \\
\hline 2013 & $1,950,441$ & 451,246 & 43,171 & $3,709,906$ & 54,910 \\
\hline 2014 & $2,220,344$ & 440,434 & 43,418 & $3,666,418$ & 52,849 \\
\hline 2015 & $2,309,276$ & 359,712 & 42,732 & $4,297,336$ & 137,462 \\
\hline 2016 & $2,451,445$ & 550,655 & 45,832 & $3,864,349$ & 132,832 \\
\hline 2017 & $2,239,878$ & 545,585 & 46,540 & $5,050,251$ & 124,836 \\
\hline 2018 & $2,433,323$ & 662,554 & 53,059 & $5,644,776$ & 130,853 \\
\hline \multicolumn{6}{|c|}{ Indonesia } \\
\hline 2011 & $1,004,524$ & 337,753 & 27,714 & $1,207,517$ & 16,639 \\
\hline 2012 & $1,100,333$ & 337,479 & 26,385 & $1,057,553$ & 17,416 \\
\hline 2013 & $1,004,205$ & 330,425 & 25,893 & $1,134,380$ & 17,042 \\
\hline 2014 & $1,037,791$ & 301,892 & 29,774 & $1,229,521$ & 28,239 \\
\hline 2015 & 958,656 & 281,780 & 28,051 & $1,139,974$ & 30,489 \\
\hline 2016 & $1,062,042$ & 296,376 & 30,100 & $1,304,872$ & 32,331 \\
\hline 2017 & $1,103,886$ & 275,663 & 30,041 & $1,457,131$ & 33,341 \\
\hline
\end{tabular}


ISSN 2356-3966 E-ISSN: 2621-2331 T. Faturohman., A. K. Maharani., Oktofa Y.S., A. Irawan., Data Envelopment ...

\begin{tabular}{|c|c|c|c|c|c|}
\hline Year & $\begin{array}{l}\text { Average Loans } \\
\text { to Customer }\end{array}$ & $\begin{array}{l}\text { Average } \\
\text { (Operating } \\
\text { income-Interest } \\
\text { income) }\end{array}$ & $\begin{array}{l}\text { Average } \\
\text { Staff } \\
\text { Expenses }\end{array}$ & $\begin{array}{l}\text { Average } \\
\text { Customer } \\
\text { Deposits }\end{array}$ & $\begin{array}{l}\text { Average Fixed } \\
\text { Assets }\end{array}$ \\
\hline 2018 & $1,486,707$ & 274,547 & 39,127 & $2,029,905$ & 54,979 \\
\hline \multicolumn{6}{|c|}{ Malaysia } \\
\hline 2011 & $3,225,755$ & 305,659 & 39,346 & $4,452,973$ & 19,046 \\
\hline 2012 & $4,191,356$ & 320,944 & 40,778 & $5,332,836$ & 27,995 \\
\hline 2013 & $4,528,542$ & 308,154 & 40,157 & $5,582,455$ & 28,931 \\
\hline 2014 & $4,821,839$ & 288,831 & 36,387 & $5,572,006$ & 24,644 \\
\hline 2015 & $4,477,038$ & 262,251 & 30,089 & $4,965,141$ & 20,049 \\
\hline 2016 & $4,723,871$ & 258,003 & 31,009 & $5,190,569$ & 17,805 \\
\hline 2017 & $6,210,824$ & 268,810 & 39,818 & $6,983,981$ & 20,874 \\
\hline 2018 & $7,120,484$ & 265,045 & 48,883 & $8,063,581$ & 26,467 \\
\hline \multicolumn{6}{|c|}{ Philippines } \\
\hline 2013 & 56,846 & 264,047 & 8,354 & 53,783 & 2,351 \\
\hline 2014 & 50,329 & 269,009 & 8,083 & 64,696 & 2,064 \\
\hline 2015 & 13,366 & 259,749 & 846 & 8,448 & 146 \\
\hline 2016 & 12,892 & 259,116 & 837 & 6,092 & 129 \\
\hline 2017 & 13,328 & 259,086 & 919 & 9,270 & 98 \\
\hline 2018 & 15,103 & 259,101 & 878 & 11,238 & 161 \\
\hline \multicolumn{6}{|c|}{ Singapore } \\
\hline 2013 & 91,608 & 268,809 & 5,519 & 751 & 468 \\
\hline 2014 & 76,391 & 270,760 & 5,227 & 296 & 369 \\
\hline 2015 & 52,568 & 263,403 & 4,985 & 31 & 6 \\
\hline \multicolumn{6}{|c|}{ Thailand } \\
\hline 2013 & $2,903,569$ & 254,446 & 43,812 & $3,096,547$ & 38,937 \\
\hline 2014 & $2,577,297$ & 227,707 & 33,528 & $3,353,165$ & 37,997 \\
\hline 2015 & $1,854,066$ & 249,218 & 21,730 & $2,685,064$ & 27,416 \\
\hline 2016 & $1,890,116$ & 268,676 & 25,132 & $2,896,899$ & 21,990 \\
\hline 2017 & $1,138,800$ & 261,517 & 24,706 & $2,641,603$ & 16,949 \\
\hline
\end{tabular}

\section{Analysis of DEA}

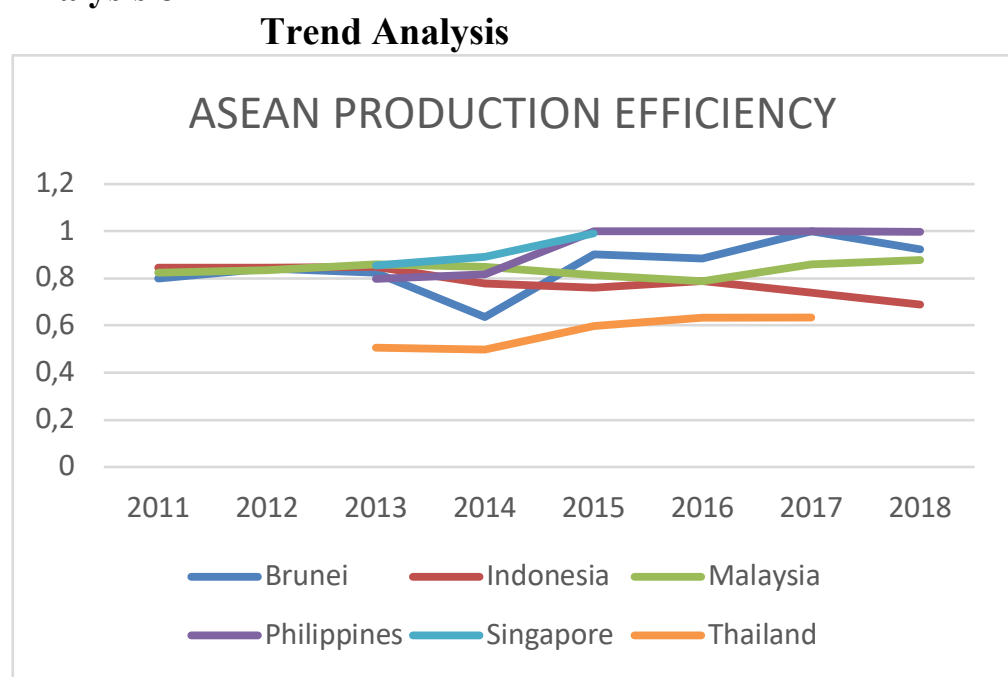

Figure 4: ASEAN Production Efficiency 


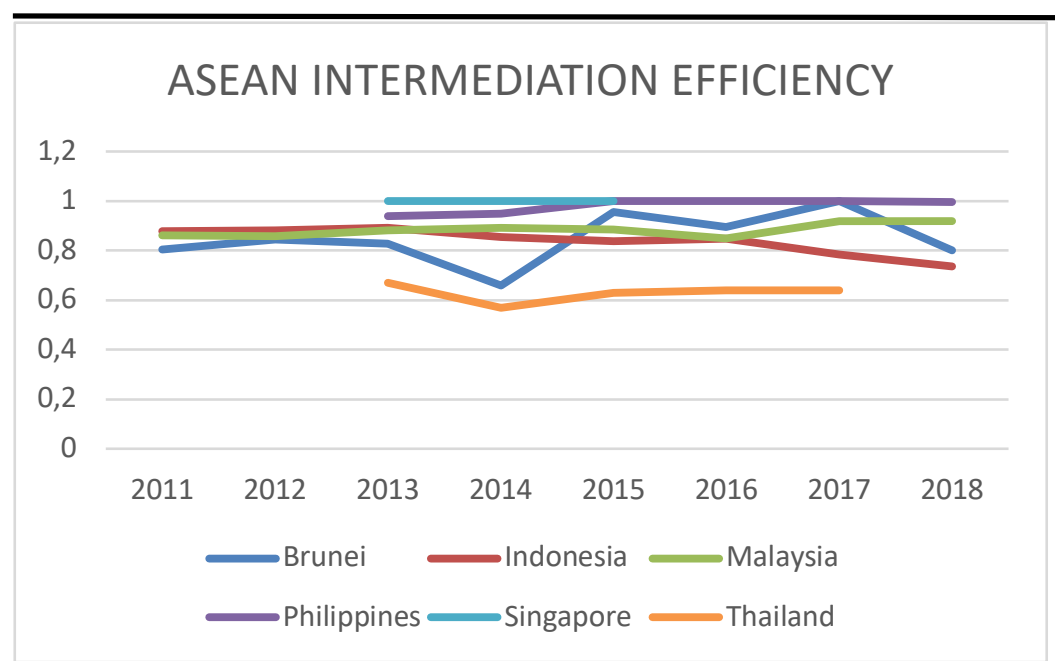

Figure 5: ASEAN Intermediation Efficiency

The two graphs above show the efficiency trend of Islamic banks relative to six ASEAN countries in eight years. Overall, Islamic banks in Thailand showed the lowest figures for intermediation and production efficiency, while the highest were the Philippines. These results will be described below with one graph per country. However, the placement of intermediation and production efficiency in one graph are not to be compared because they are in different frontiers.

1. Brunei

Table 4: Efficiency Scores of Brunei Islamic Bank

\begin{tabular}{|l|l|l|l|}
\hline Year & Number of Bank & $\begin{array}{l}\text { VRSTE } \\
\text { Intermediation }\end{array}$ & VRSTE Production \\
\hline 2011 & 1 & 0.805 & 0.801 \\
\hline 2012 & 1 & 0.845 & 0.842 \\
\hline 2013 & 1 & 0.827 & 0.824 \\
\hline 2014 & 1 & 0.659 & 0.636 \\
\hline 2015 & 1 & 0.957 & 0.902 \\
\hline 2016 & 1 & 0.895 & 0.886 \\
\hline 2017 & 1 & 1 & 1 \\
\hline 2018 & 1 & 0.801 & 0.923 \\
\hline
\end{tabular}

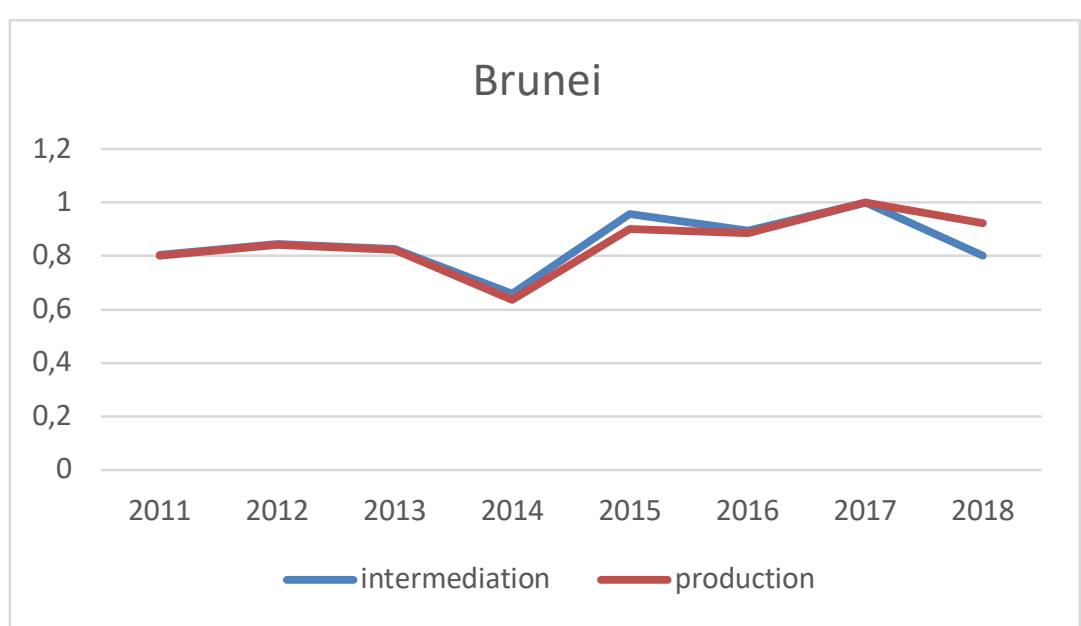

Figure 6: Efficiency Trend of Brunei Islamic Bank

Fluctuations in efficiency scores of Islamic bank in Brunei occur from year to year both from intermediation and production approaches. In 2014 efficiency dropped from the previous year and rose again in 2015. In 2017 to 2018 
efficiency also experienced a significant decline from 1 to 0.801 in intermediation and 1 to 0.923 in production approach. The efficiency scroe of Islamic bank in Brunei is ranging from the highest of 1 for both intermediation and production approaches to the lowest of 0.659 for intermediation approach and 0.636 for production approach.

2. Indonesia

Table 5: Efficiency Scores of Indonesian Islamic Banks

\begin{tabular}{|c|c|c|c|c|c|c|c|c|}
\hline \multirow{2}{*}{$\begin{array}{l}\text { Number } \\
\text { of Bank }\end{array}$} & \multicolumn{4}{|c|}{ Intermediation } & \multicolumn{4}{|c|}{ Production } \\
\hline & Min & Max & Stdv & Average & Min & Max & Stdv & Average \\
\hline \multicolumn{9}{|l|}{2011} \\
\hline 9 & 0.614 & 1 & 0.142 & 0.879 & 0.589 & 1 & 0.147 & 0.847 \\
\hline \multicolumn{9}{|l|}{2012} \\
\hline 10 & 0.682 & 1 & 0.147 & 0.880 & 0.590 & 1 & 0.147 & 0.846 \\
\hline \multicolumn{9}{|l|}{2013} \\
\hline 11 & 0.635 & 1 & 0.130 & 0.892 & 0.562 & 1 & 0.152 & 0.849 \\
\hline \multicolumn{9}{|l|}{2014} \\
\hline 11 & 0.587 & 1 & 0.133 & 0.854 & 0.344 & 1 & 0.182 & 0.777 \\
\hline \multicolumn{9}{|l|}{2015} \\
\hline 11 & 0.588 & 1 & 0.149 & 0.837 & 0.379 & 0.965 & 0.178 & 0.759 \\
\hline \multicolumn{9}{|l|}{2016} \\
\hline 11 & 0.617 & 1 & 0.141 & 0.849 & 0.385 & 0.979 & 0.175 & 0.788 \\
\hline \multicolumn{9}{|l|}{2017} \\
\hline 11 & 0.580 & 1 & 0.130 & 0.784 & 0.386 & 1 & 0.168 & 0.738 \\
\hline \multicolumn{9}{|l|}{2018} \\
\hline 6 & 0.503 & 0.968 & 0.166 & 0.736 & 0.365 & 0.947 & 0.195 & 0.689 \\
\hline
\end{tabular}

Broadly speaking, the efficiency of Islamic banks in Indonesia has continued to decline from 2011 to 2018 even though it rose in 2013 and 2016 from their previous year. The intermediation and production approach are moving almost simultaneously.

3. Malaysia

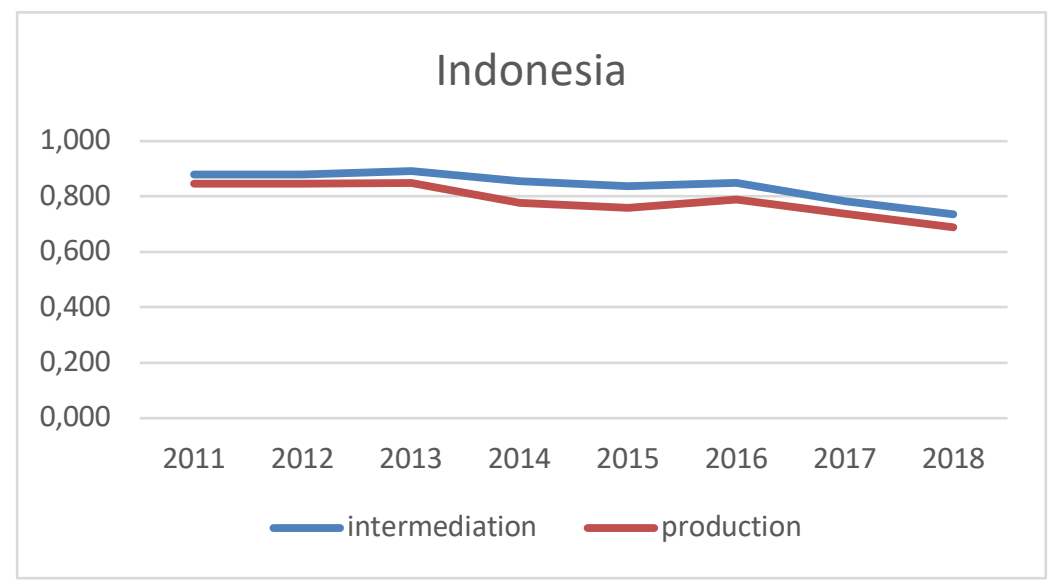

Figure 7: Trend Efficiency of Indonesian Islamic Banks 
Table 6: Efficiency Score of Malaysian Islamic Banks

\begin{tabular}{|c|c|c|c|c|c|c|c|c|}
\hline \multirow{2}{*}{$\begin{array}{l}\text { Number } \\
\text { of Bank }\end{array}$} & \multicolumn{4}{|c|}{ Intermediation } & \multicolumn{4}{|c|}{ Production } \\
\hline & Min & Max & Stdv & Average & Min & Max & Stdv & Average \\
\hline \multicolumn{9}{|l|}{2011} \\
\hline 18 & 0.615 & 1 & 0.130 & 0.861 & 0.132 & 1 & 0206 & 0.823 \\
\hline \multicolumn{9}{|l|}{2012} \\
\hline 18 & 0.609 & 1 & 0.124 & 0.858 & 0.596 & 1 & 0.139 & 0.836 \\
\hline \multicolumn{9}{|l|}{2013} \\
\hline 18 & 0.690 & 1 & 0.100 & 0.883 & 0.636 & 1 & 0.115 & 0.860 \\
\hline \multicolumn{9}{|l|}{2014} \\
\hline 18 & 0.713 & 1 & 0.094 & 0.893 & 0.681 & 1 & 0.110 & 0.848 \\
\hline \multicolumn{9}{|l|}{2015} \\
\hline 18 & 0.648 & 1 & 0.095 & 0.885 & 0.627 & 0.100 & 0.117 & 0.813 \\
\hline \multicolumn{9}{|l|}{2016} \\
\hline 18 & 0.617 & 1 & 0.141 & 0.849 & 0.385 & 0.979 & 0.175 & 0.788 \\
\hline \multicolumn{9}{|l|}{2017} \\
\hline 17 & 0.701 & 1 & 0.107 & 0.917 & 0.628 & 1 & 0.147 & 0.859 \\
\hline \multicolumn{9}{|l|}{2018} \\
\hline 13 & 0.730 & 1 & 0.090 & 0.919 & 0.673 & 1 & 0.115 & 0.878 \\
\hline
\end{tabular}

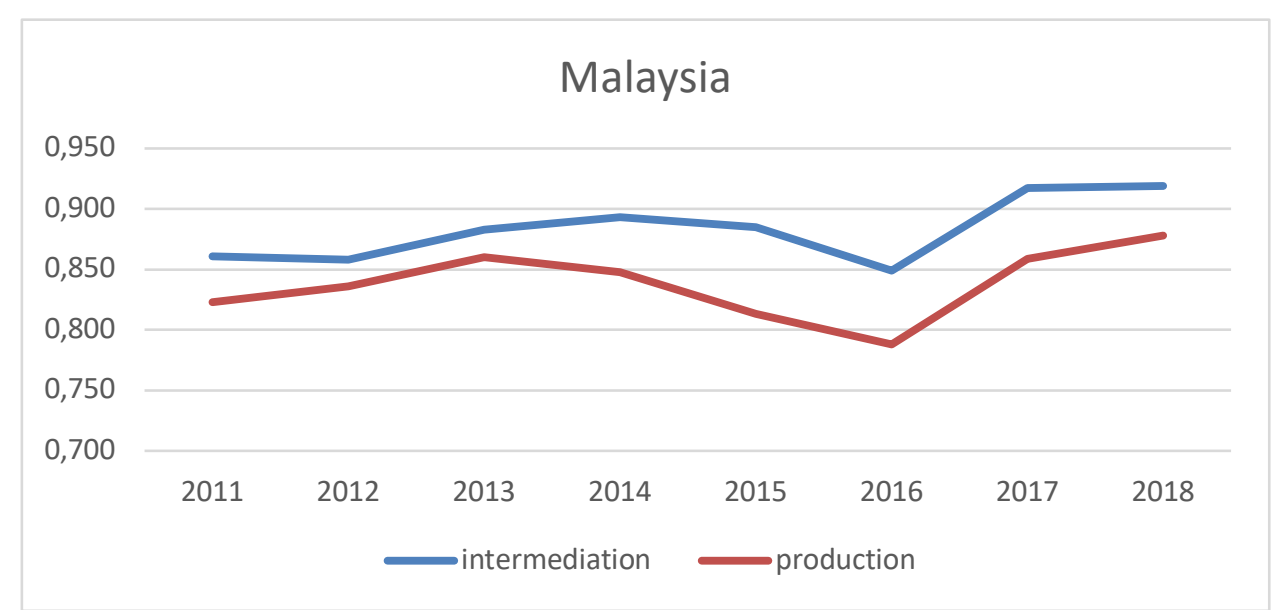

Figure 8: Trend Efficiency of Malaysian Islamic Banks

The average efficiency score of Islamic bank in Malaysia is quite fluctuating with a minimum score of 0.617 for the intermediation approach and 0.385 for the production approach, both of which occur in the same year, namely 2016 . The highest score of efficiency was achieved in 2018 with 0.919 under intermediation approach and 0.878 under production approach. 
4. Philippines

Table 7: Efficiency Score of Philippines Islamic Bank

\begin{tabular}{|l|l|l|l|}
\hline Year & Number of bank & VRSTE Intermediation & VRSTE Production \\
\hline 2013 & 1 & 0.939 & 0.798 \\
\hline 2014 & 1 & 0.949 & 0.816 \\
\hline 2015 & 1 & 1 & 1 \\
\hline 2016 & 1 & 1 & 1 \\
\hline 2017 & 1 & 1 & 1 \\
\hline 2018 & 1 & 0.997 & 0.996 \\
\hline
\end{tabular}

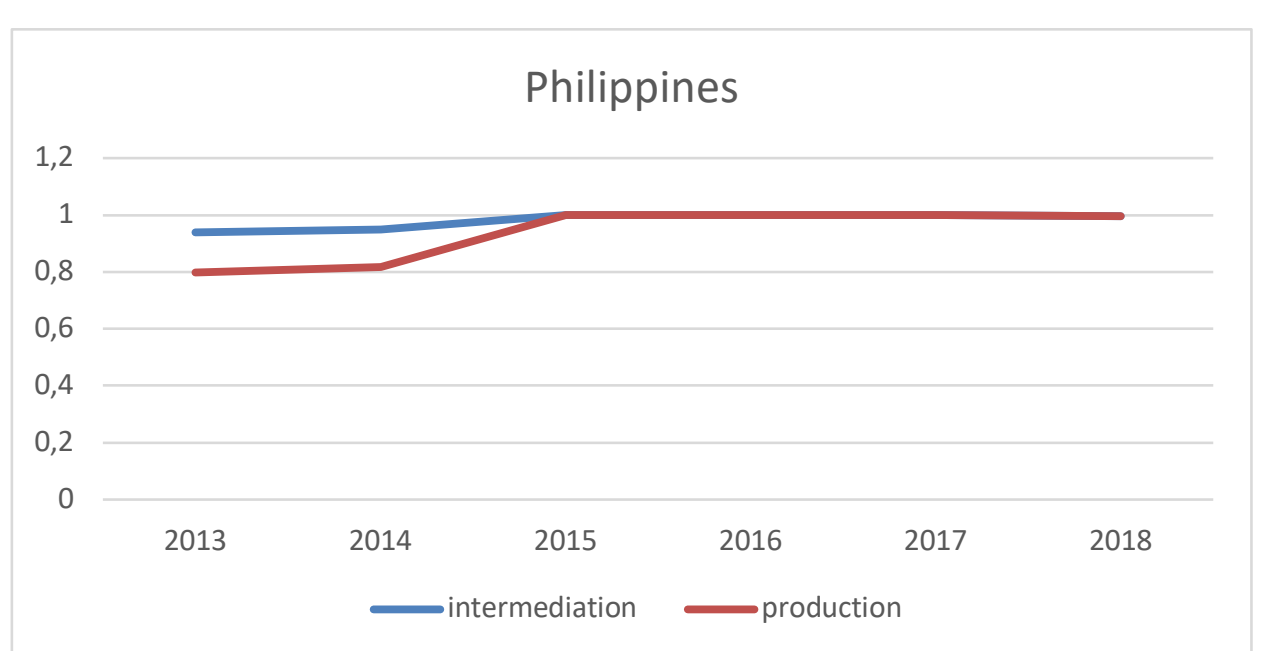

Figure 9: Trend Efficiency of Philippines Islamic Bank

The efficiency of Islamic banks in Philippines continues to increase under both intermediation and production approaches from 2013 to 2017, then it dropped slightly in 2018 from 1 under both intermediation and production approaches to 0.997 and 0.996 , respectively.

5. Singapore

Table 8: Efficiency Score of Singaporean Islamic Banks

\begin{tabular}{|l|l|l|l|}
\hline Year & Number of bank & VRSTE Intermediation & VRSTE Production \\
\hline 2013 & 1 & 1 & 0.855 \\
\hline 2014 & 1 & 1 & 0.891 \\
\hline 2015 & 1 & 1 & 0.991 \\
\hline
\end{tabular}




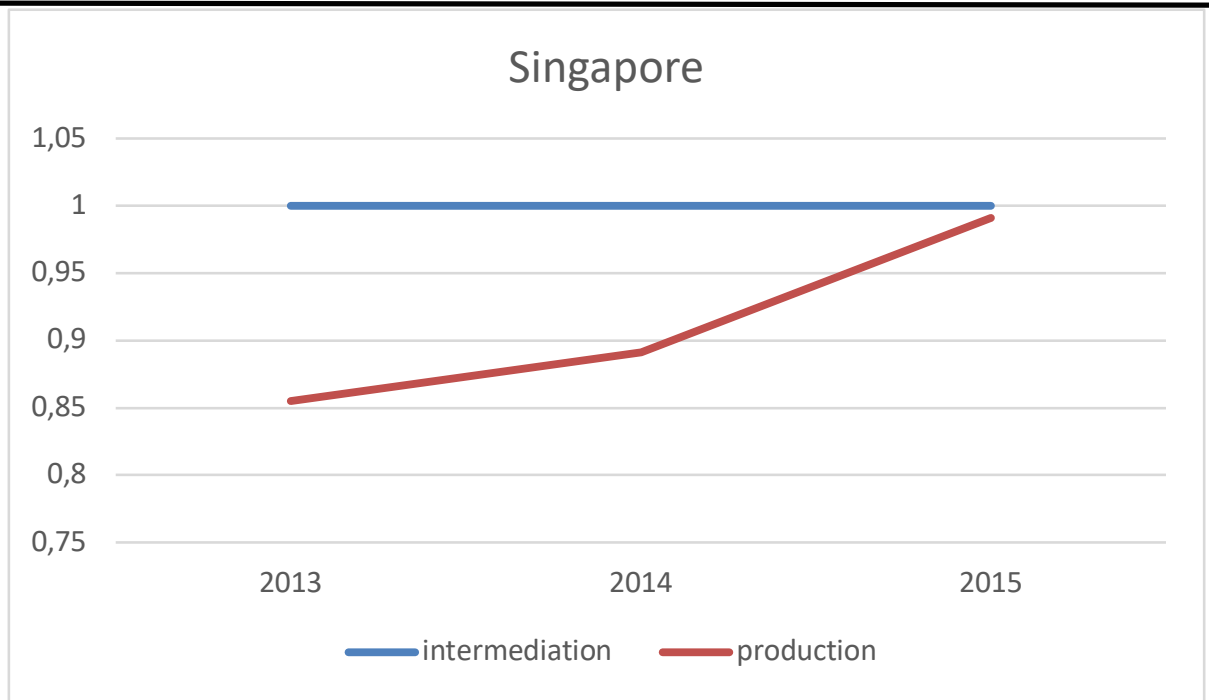

Figure 10: Trend Efficiency of Singaporean Islamic Bank

The efficiency of Islamic banks in Singapore is stable with a score of 1 from 2013-2015 under intermediation approach. While for the production approach, the score below intermediation continues to increase from 0.855 in 2013 to 0.991 in 2015. however, as the only Islamic bank in Singapore, Islamic Bank of Asia was winded down by its parent company, DBS Holding Groups after 3 years of operation due to its unability to achieve economies of scale (Yahya, 2015).

6. Thailand

Table 9 : Efficiency Score of Thailand Islamic Bank

\begin{tabular}{|l|l|l|l|}
\hline Year & Number of bank & VRSTE Intermediation & VRSTE Production \\
\hline 2013 & 1 & 0.67 & 0.507 \\
\hline 2014 & 1 & 0.569 & 0.498 \\
\hline 2015 & 1 & 0.628 & 0.599 \\
\hline 2016 & 1 & 0.64 & 0.633 \\
\hline 2017 & 1 & 0.641 & 0.634 \\
\hline
\end{tabular}

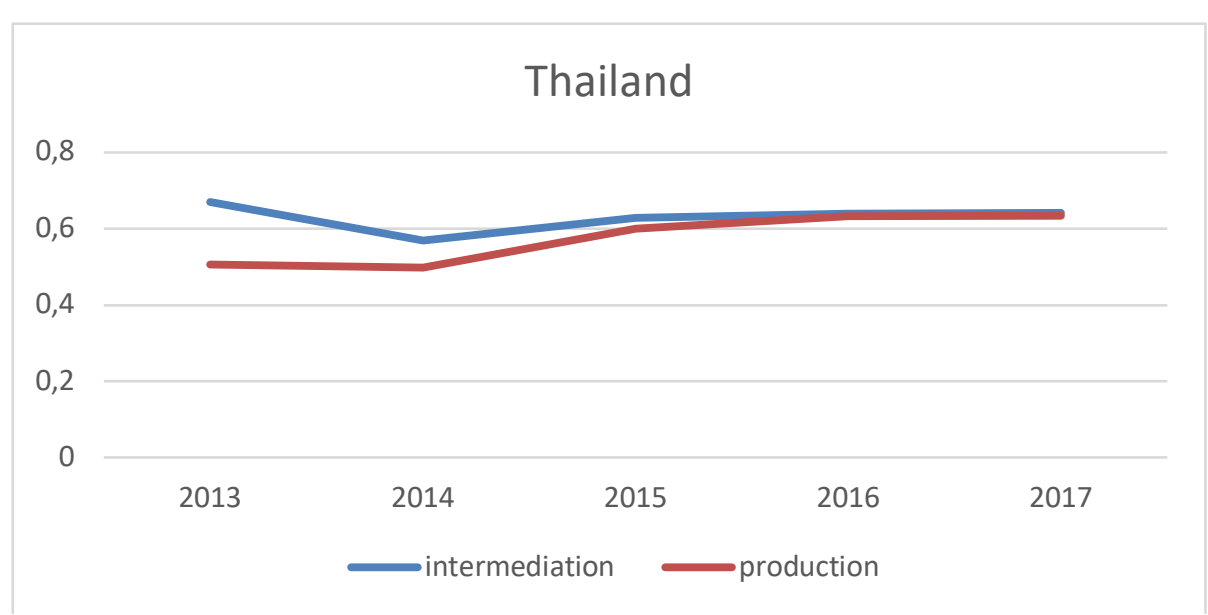

Figure 11: Trend Efficiency of Thailand Islamic Bank

Both intermediation and production approach efficiency score are declining in 2014 from their previous year, then they rise in 2014 and keep showing positive trends for both approaches until 2017. However, there is no further information about Islamic Bank of Thailand after 2017. Both approaches for the country are ranging from the lowest of 0.498 to the highest of 0.6 . 


\section{Cross-Sectional Analysis}

1. 2011

Table 10: 2011 Cross-Sectional Efficiency

\begin{tabular}{|c|c|c|c|c|c|c|c|c|}
\hline \multirow{2}{*}{$\begin{array}{l}\text { Number } \\
\text { of Bank }\end{array}$} & \multicolumn{4}{|c|}{ Intermediation } & \multicolumn{4}{|c|}{ Production } \\
\hline & Min & Max & Stdv & Average & Min & Max & Stdv & Average \\
\hline \multicolumn{9}{|l|}{ Brunei } \\
\hline 1 & 0.919 & 0.919 & - & 0.919 & 0.859 & 0.859 & - & 0.859 \\
\hline \multicolumn{9}{|c|}{ Indonesia } \\
\hline 9 & 0.701 & 1 & 0.107 & 0.941 & 0.592 & 1 & 0.145 & 0.880 \\
\hline \multicolumn{9}{|l|}{ Malaysia } \\
\hline 18 & 0.625 & 1 & 0.128 & 0.895 & 0.226 & 1 & 0.224 & 0.812 \\
\hline
\end{tabular}

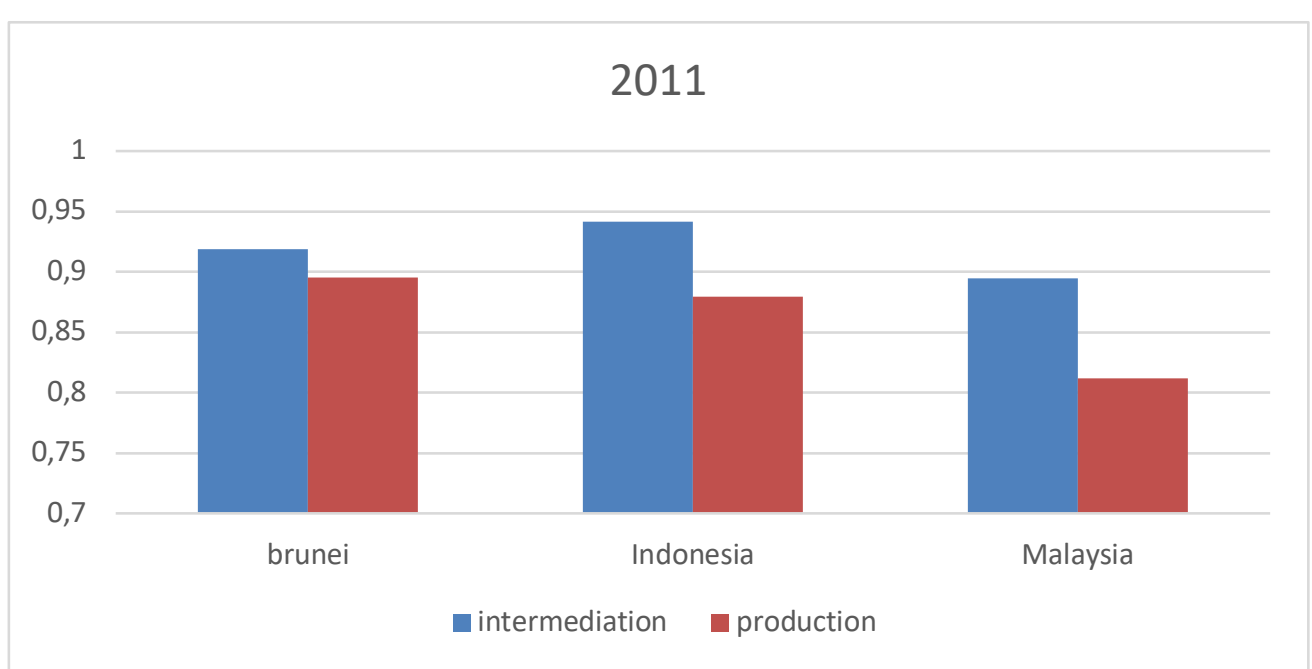

Figure 12: 2011 Cross-sectional Efficiency

In 2011 Indonesian Islamic banks has the highest average DEA efficiency value relative to Brunei and Malaysia when viewed from the intermediation function. Brunei holds the best efficiency score viewed in production approach.

2. 2012

Table 11: 2012 Cross-sectional Efficiency

\begin{tabular}{|l|l|l|l|l|l|l|l|l|}
\hline \multirow{2}{*}{$\begin{array}{l}\text { Number } \\
\text { of Bank }\end{array}$} & Intermediation & Production & \\
\hline Brunei & Min & Max & Stdv & Average & Min & Max & Stdv & Average \\
\hline 1 & 0.839 & 0.839 & - & 0.839 & 0.831 & 0.831 & - & 0.831 \\
\hline Indonesia & 0.687 & 1 & 0.125 & 0.908 & 0.456 & 1 & 0.208 & 0.821 \\
\hline 10 & 0.151 & 0.877 & 0.433 & 1 & 0.214 & 0.778 \\
\hline Malaysia
\end{tabular}




\section{2}

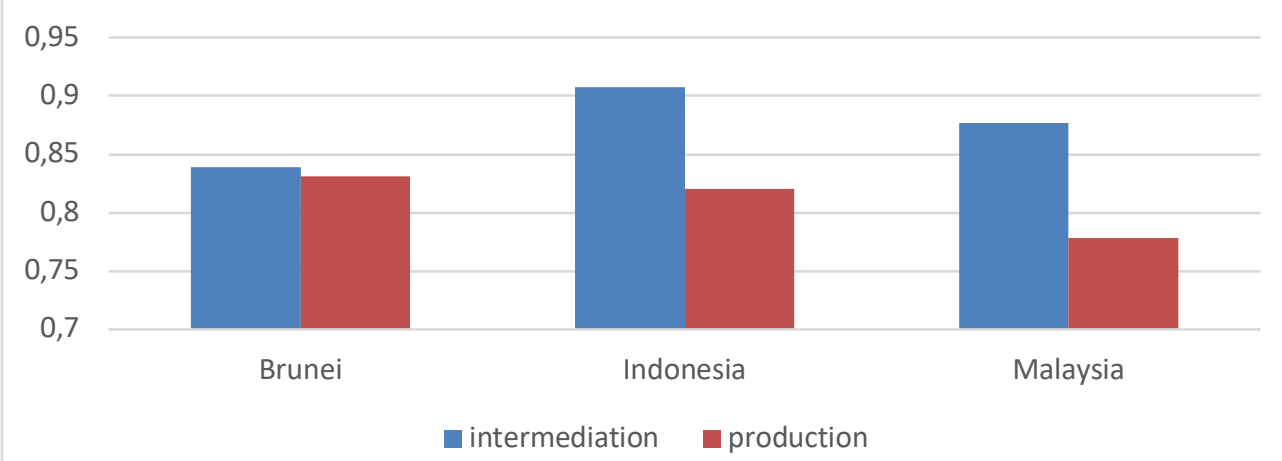

Figure 13: 2012 Cross-sectional Efficiency

In 2012 the efficiency of Islamic banks in Indonesia still stood as the highest as intermediaries while as producers, the Islamic bank in Brunei was the champ.
3. 2013

Table 12: 2013 Cross-sectional Efficiency

\begin{tabular}{|c|c|c|c|c|c|c|c|c|}
\hline \multirow{2}{*}{$\begin{array}{l}\text { Number } \\
\text { of Bank }\end{array}$} & \multicolumn{4}{|c|}{ Intermediation } & \multicolumn{4}{|c|}{ Production } \\
\hline & Min & Max & Stdv & Average & Min & Max & Stdv & Average \\
\hline \multicolumn{9}{|l|}{ Brunei } \\
\hline 1 & 0934 & 0.934 & - & 0.934 & 0.773 & 0.773 & - & 0.773 \\
\hline \multicolumn{9}{|c|}{ Indonesia } \\
\hline 11 & 0.664 & 1 & 0.138 & 0.817 & 0.355 & 1 & 0.239 & 0.809 \\
\hline \multicolumn{9}{|c|}{ Malaysia } \\
\hline 18 & 0.533 & 1 & 0.133 & 0.922 & 0.655 & 1 & 0.107 & 0.920 \\
\hline \multicolumn{9}{|c|}{ Philippines } \\
\hline 1 & 1 & 1 & - & 1 & 1 & 1 & - & 1 \\
\hline \multicolumn{9}{|c|}{ Singapore } \\
\hline 1 & 1 & 1 & - & 1 & 1 & 1 & - & 1 \\
\hline \multicolumn{9}{|l|}{ Thailand } \\
\hline 1 & 1 & 1 & - & 1 & 1 & 1 & - & 1 \\
\hline
\end{tabular}

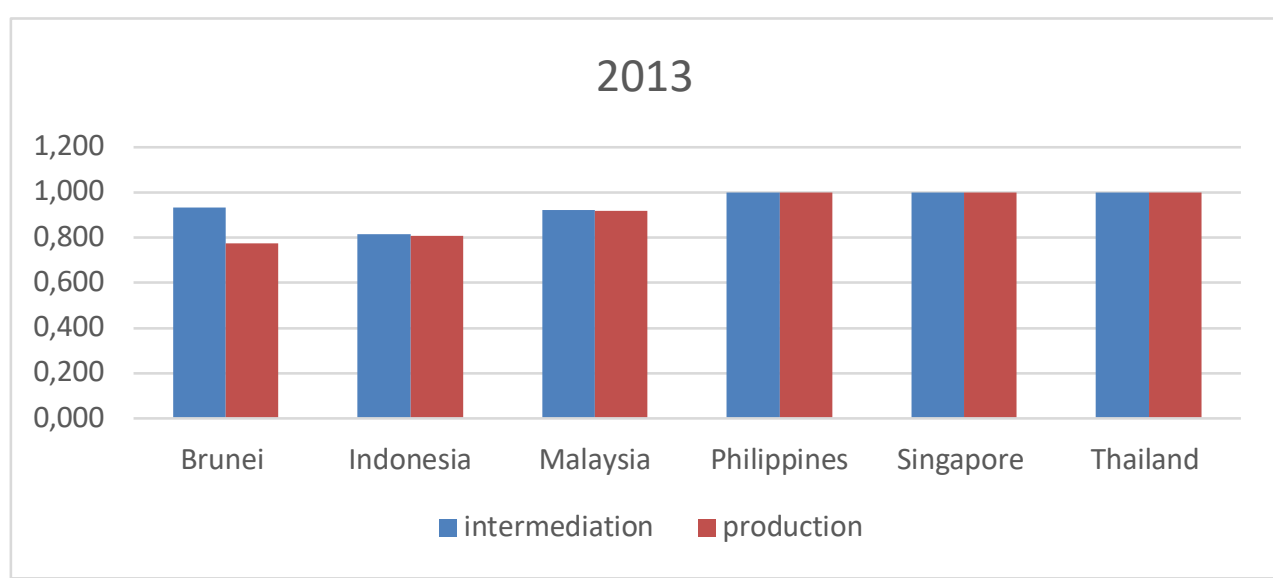

Figure 14: 2013 Cross-sectional Efficiency

According to data obtained, the number of countries involved in 2013 increased with the presence of Philippines, Singapore, and Thailand. The newcomers immediately won the highest efficiency value relative to Brunei, Indonesia and Malaysia both in terms of intermediation and production. The second highest efficiency score from the intermediation approach was achieved by Brunei with a score of 0.934 and the lowest Indonesia with a score of 0.817 , 
whereas from the intermediation approach the highest efficiency score was followed by Malaysia at 0.920 and the lowest Brunei with a score of 0.773 .

4. 2014

Table 13: 2014 Cross-sectional Efficiency

\begin{tabular}{|c|c|c|c|c|c|c|c|c|}
\hline \multirow{2}{*}{$\begin{array}{l}\text { Number } \\
\text { of Bank }\end{array}$} & \multicolumn{4}{|c|}{ Intermediation } & \multicolumn{4}{|c|}{ Production } \\
\hline & Min & Max & Stdv & Average & Min & Max & Stdv & Average \\
\hline \multicolumn{9}{|c|}{ Brunei } \\
\hline 1 & 0.782 & 0.782 & - & 0.782 & 0.818 & 0.818 & - & 0.818 \\
\hline \multicolumn{9}{|c|}{ Indonesia } \\
\hline 11 & 0.645 & 1 & 0.130 & 0.869 & 0.297 & 1 & 0.204 & 0.791 \\
\hline \multicolumn{9}{|l|}{ Malaysia } \\
\hline 18 & 0.703 & 1 & 0.099 & 0.938 & 0.713 & 1 & 0.106 & 0.910 \\
\hline \multicolumn{9}{|c|}{ Philippines } \\
\hline 1 & 0.920 & 0.920 & - & 0.920 & 0.891 & 0.891 & - & 0.891 \\
\hline \multicolumn{9}{|c|}{ Singapore } \\
\hline 1 & 1 & 1 & - & 1 & 1 & 1 & - & 1 \\
\hline \multicolumn{9}{|l|}{ Thailand } \\
\hline 1 & 0.652 & 0.652 & - & 0.652 & 0.402 & 0.402 & - & 0.402 \\
\hline
\end{tabular}

\section{4}

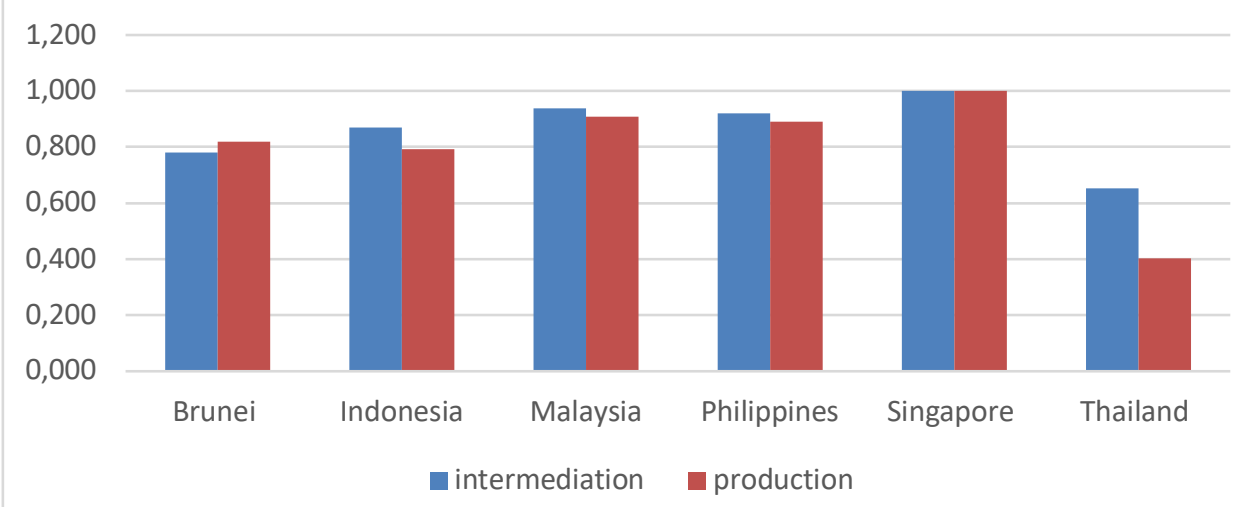

Figure 15: 2014 Cross-sectional Efficiency

In 2014 Singapore still held the highest efficiency value relative to other ASEAN countries by both intermediation and production approach with a value of 1 . The country order from the highest to the lowest in intermediation are Singapore, Malaysia, Philippines, Indonesia, Brunei and Thailand while for the production approach are Singapore, Malaysia, Philippines, Brunei, Indonesia and Thailand.

$$
\text { 5. } 2015
$$

Table 14: 2015 Cross-sectional Efficiency

\begin{tabular}{|c|c|c|c|c|c|c|c|c|}
\hline \multirow{2}{*}{$\begin{array}{l}\text { Number } \\
\text { of Bank }\end{array}$} & \multicolumn{4}{|c|}{ Intermediation } & \multicolumn{4}{|c|}{ Production } \\
\hline & Min & Max & Stdv & Average & Min & Max & Stdv & Average \\
\hline \multicolumn{9}{|l|}{ Brunei } \\
\hline 1 & 1 & 1 & - & 1 & 1 & 1 & - & 1 \\
\hline \multicolumn{9}{|c|}{ Indonesia } \\
\hline 11 & 0.728 & 1 & 0.111 & 0.892 & 0.286 & 1 & 0.227 & 0.815 \\
\hline \multicolumn{9}{|c|}{ Malaysia } \\
\hline 18 & 0.706 & 1 & 0.090 & 0.936 & 0.639 & 1 & 0.116 & 0.899 \\
\hline \multicolumn{9}{|c|}{ Philippines } \\
\hline 1 & 1 & 1 & - & 1 & 1 & 1 & - & 1 \\
\hline
\end{tabular}




\begin{tabular}{|c|c|c|c|c|c|c|c|c|}
\hline \multirow{2}{*}{$\begin{array}{l}\text { Number } \\
\text { of Bank }\end{array}$} & \multicolumn{4}{|c|}{ Intermediation } & \multicolumn{4}{|c|}{ Production } \\
\hline & Min & Max & Stdv & Average & Min & Max & Stdv & Average \\
\hline \multicolumn{9}{|c|}{ Singapore } \\
\hline 1 & 1 & 1 & - & 1 & 1 & 1 & - & 1 \\
\hline \multicolumn{9}{|l|}{ Thailand } \\
\hline 1 & 0.623 & 0.623 & - & 0.623 & 0.585 & 0.585 & - & 0.585 \\
\hline
\end{tabular}

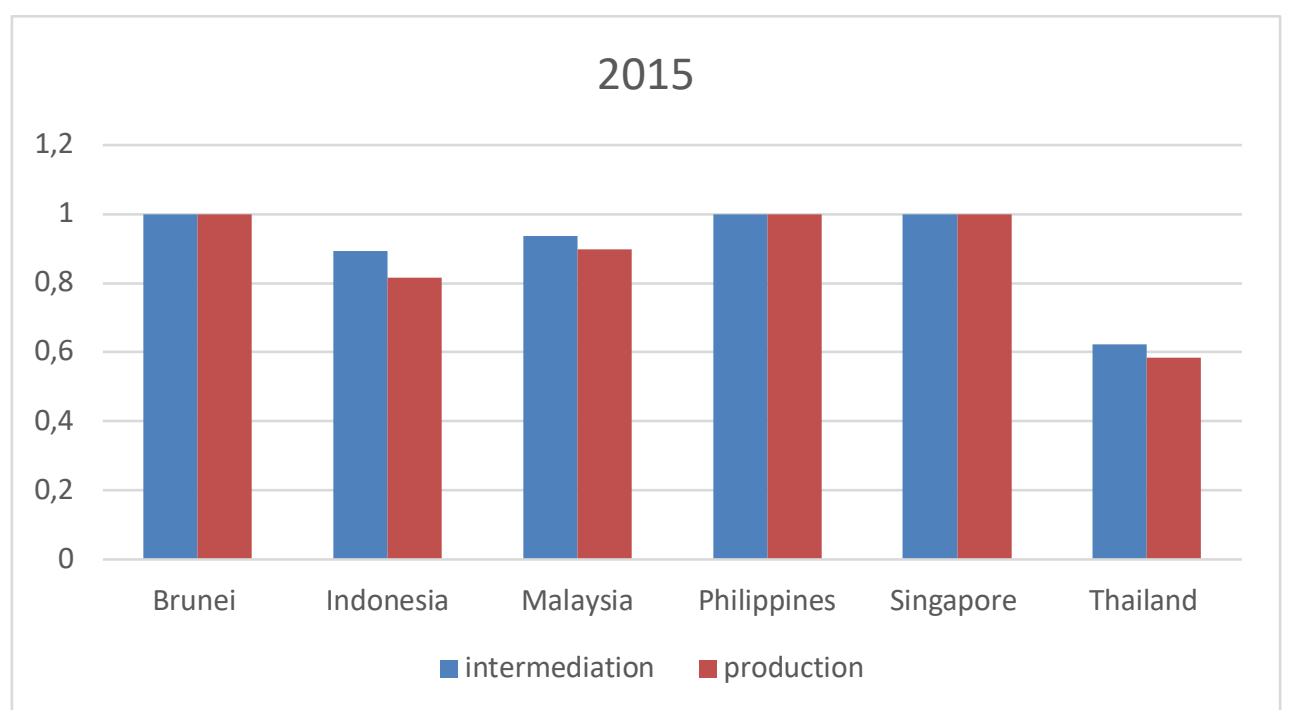

Figure 16: 2015 Cross-sectional Efficiency

Singapore still has the highest efficiency relative to other ASEAN countries in 2015 followed by Brunei and the Philippines with a score of one for both approaches, intermediation and production. The highest intermediation result is followed by Malaysia, Indonesia and Thailand, as well as the production approach.

6. 2016

Table 15: 2016 Cross-Sectional Efficiency

\begin{tabular}{|c|c|c|c|c|c|c|c|c|}
\hline \multirow{2}{*}{$\begin{array}{l}\text { Number } \\
\text { of Bank }\end{array}$} & \multicolumn{4}{|c|}{ Intermediation } & \multicolumn{4}{|c|}{ Production } \\
\hline & Min & Max & Stdv & Average & Min & Max & Stdv & Average \\
\hline \multicolumn{9}{|l|}{ Brunei } \\
\hline 1 & 1 & 1 & - & 1 & 1 & 1 & - & 1 \\
\hline \multicolumn{9}{|c|}{ Indonesia } \\
\hline 11 & 0.740 & 1 & 0.081 & 0.927 & 0.332 & 1 & 0.210 & 0.828 \\
\hline \multicolumn{9}{|c|}{ Malaysia } \\
\hline 18 & 0.714 & 1 & 0.091 & 0.942 & 0.703 & 1 & 0.099 & 0.935 \\
\hline \multicolumn{9}{|c|}{ Philippines } \\
\hline 1 & 1 & 1 & - & 1 & 1 & 1 & - & 1 \\
\hline \multicolumn{9}{|l|}{ Thailand } \\
\hline 1 & 0.651 & 0.651 & - & 0.651 & 0.652 & 0.652 & - & 0.652 \\
\hline
\end{tabular}




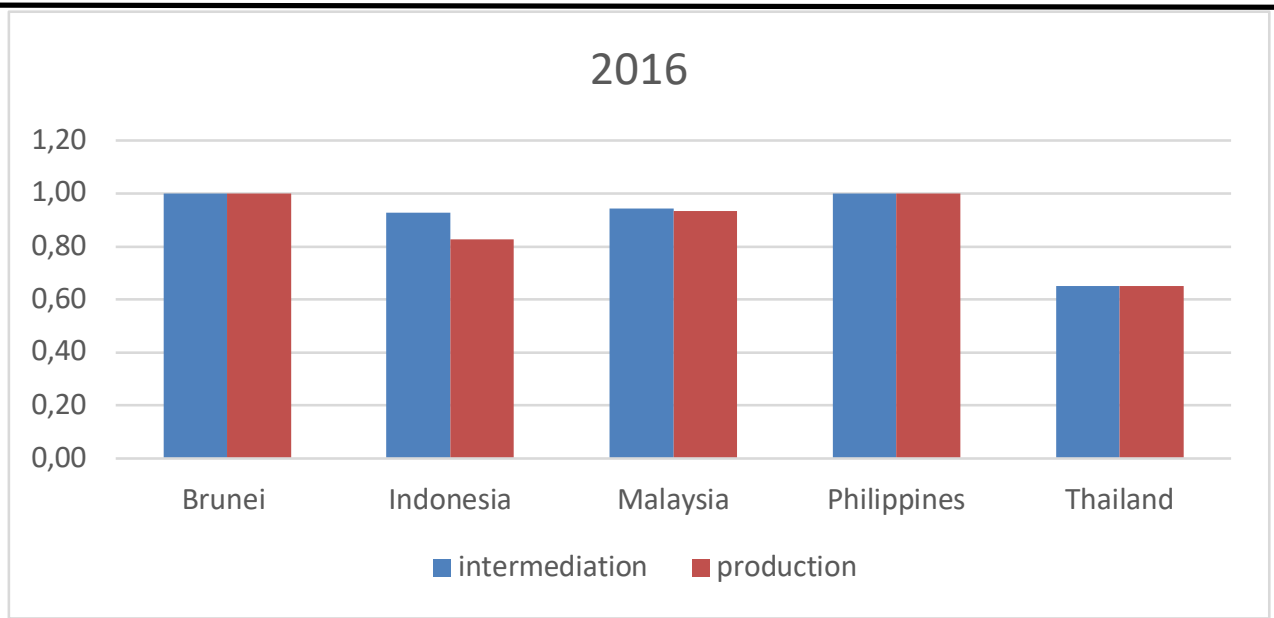

Figure 17: Cross-sectional Efficiency

In 2016 the Philippines and Brunei had the highest efficiency scores under both intermediation and production approaches with a score of one. Followed by Malaysia, Indonesia and Thailand.

7. 2017

Table 16: 2017 Cross-sectional Efficiency

\begin{tabular}{|c|c|c|c|c|c|c|c|c|}
\hline \multirow{2}{*}{$\begin{array}{l}\text { Number } \\
\text { of Bank }\end{array}$} & \multicolumn{4}{|c|}{ Intermediation } & \multicolumn{4}{|c|}{ Production } \\
\hline & Min & Max & Stdv & Average & Min & Max & Stdv & Average \\
\hline \multicolumn{9}{|l|}{ Brunei } \\
\hline 1 & 1 & 1 & - & 1 & 1 & 1 & - & 1 \\
\hline \multicolumn{9}{|c|}{ Indonesia } \\
\hline 11 & 0.678 & 1 & 0.102 & 0.894 & 0.333 & 1 & 0.196 & 0.787 \\
\hline \multicolumn{9}{|c|}{ Malaysia } \\
\hline 17 & 0.741 & 1 & 0.087 & 0.943 & 0.688 & 1 & 0.122 & 0.896 \\
\hline \multicolumn{9}{|c|}{ Philippines } \\
\hline 1 & 1 & 1 & - & 1 & 1 & 1 & - & 1 \\
\hline \multicolumn{9}{|l|}{ Thailand } \\
\hline 1 & 0.684 & 0.684 & - & 0.684 & 0.680 & 0.680 & - & 0.680 \\
\hline
\end{tabular}

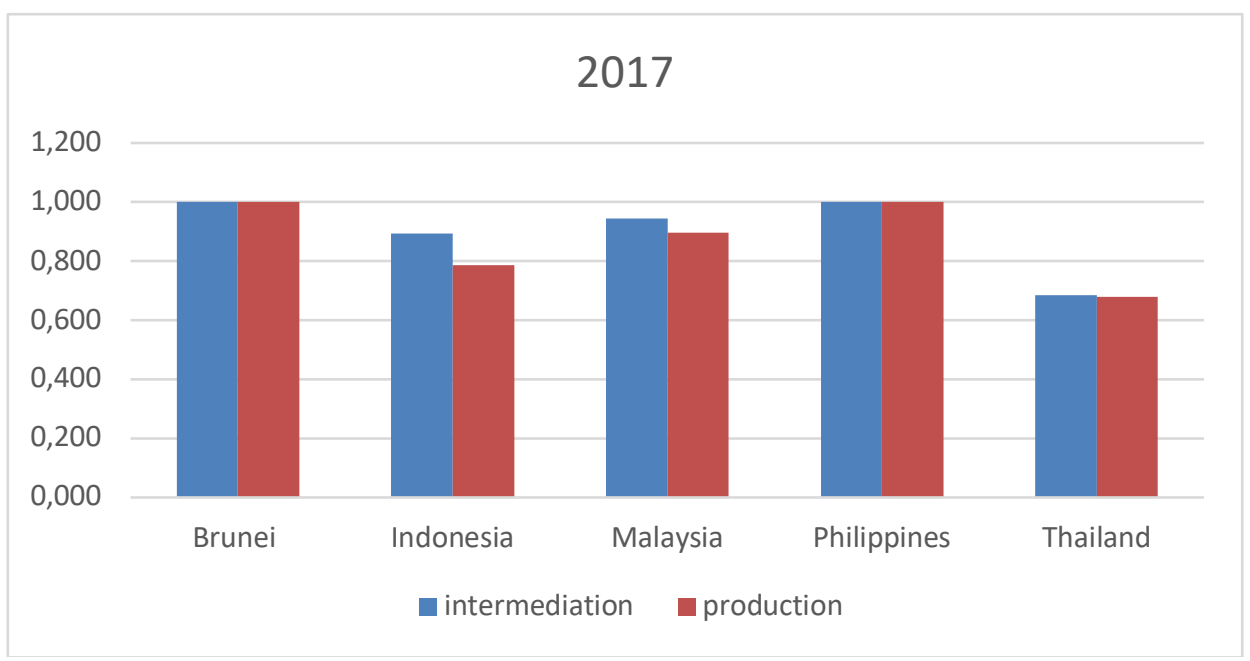

Figure 18: 2017 Cross-sectional Efficiency

Brunei and Philippines still have the highest efficiency in 2017 relative to Indonesia, Malaysia, and Thailand with a score of 1 under both approaches. Followed by Malaysia, Indonesia and Thailand.

8. 2018 


\begin{tabular}{|c|c|c|c|c|c|c|c|c|}
\hline \multirow{2}{*}{$\begin{array}{l}\text { Number } \\
\text { of Bank }\end{array}$} & \multicolumn{4}{|c|}{ Intermediation } & \multicolumn{4}{|c|}{ Production } \\
\hline & Min & Max & Stdv & Average & Min & Max & Stdv & Average \\
\hline \multicolumn{9}{|l|}{ Brunei } \\
\hline 1 & 1 & 1 & - & 1 & 1 & 1 & - & 1 \\
\hline \multicolumn{9}{|c|}{ Indonesia } \\
\hline 6 & 0.667 & 0.995 & 0.115 & 1 & 0.115 & 0.995 & 0.194 & 0.845 \\
\hline \multicolumn{9}{|c|}{ Malaysia } \\
\hline 13 & 0.921 & 1.000 & 0.028 & 0.987 & 0.934 & 1.000 & 0.025 & 0.987 \\
\hline \multicolumn{9}{|c|}{ Philippines } \\
\hline 1 & 1 & 1 & - & 1 & 1 & 1 & - & 1 \\
\hline
\end{tabular}

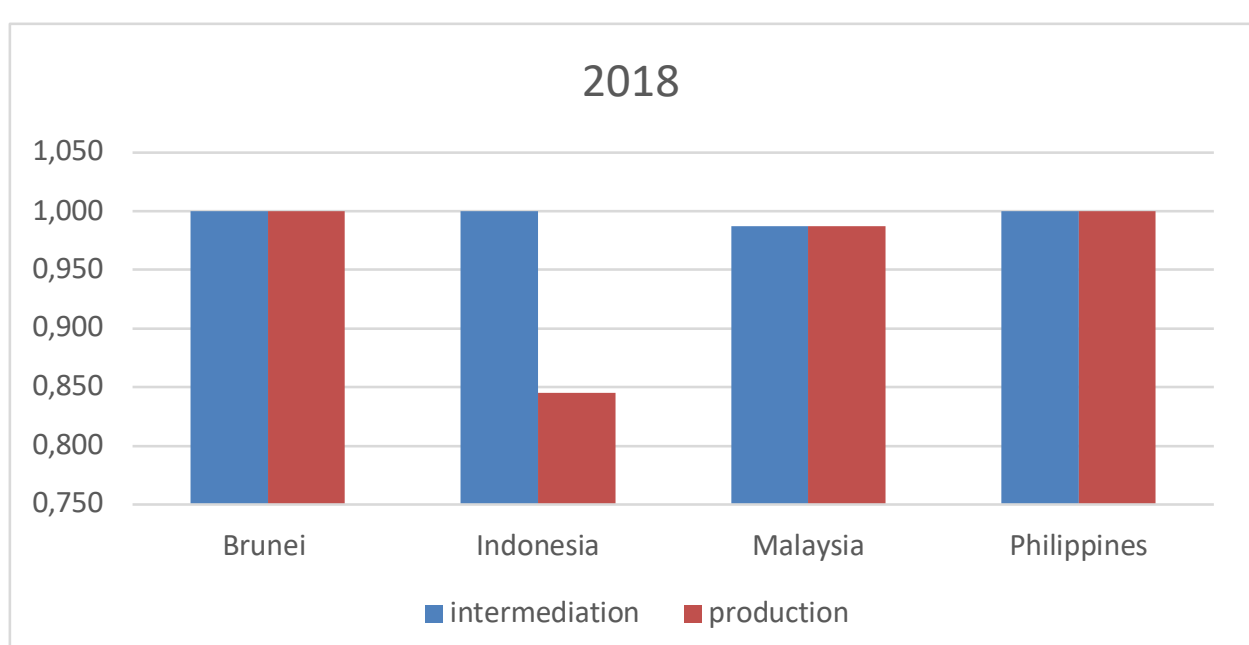

Figure 19: 2018 Cross-sectional Efficiency

Under intermediation approach, Islamic banks Brunei, Philippines, and Indonesia has the same efficiency score of 1 followed by Malaysia with the score of 0.987 . There is a notable difference between intermediation and production efficiency of Islamic banks in Indonesia compared to other countries that year.

\section{Discussion}

Results for efficiencies indicate that there are differences in average Islamic bank efficiency across countries in ASEAN, with Singapore and Philippines Islamic banks being the most efficient, followed Brunei, Malaysia, Indonesia, and Thailand examined in a single-multiyear frontier.

This research found that Islamic banks in the Philippines and Singapore have the highest efficiency in ASEAN. This findings can be explained by Karim (2001). He found that inefficiency decreases with bank size. In fact, Islamic banks in the Philippines and Singapore have much smaller size than their counterparts in ASEAN countries. This is reflected by their smaller fixed assets. They also have the least staff expenses in ASEAN.

The result shows that Islamic banks in Thailand is the least efficient in ASEAN countries. This is reflected by the combination of higher input and lower output in comparison to other countries. One of the possibilities is Islamic bank in Thailand is owned by government. Earlier study found that state-owned banks are less efficient than the private banks. In fact the most efficient Islamic banks in ASEAN are located in Singapore and Philippines. These banks are owned by private parties. This finding is in line with earlier study (Karas, Schoors, \& Weill, 2010).

Two countries with the highest number of Islamic banks, Malaysia and Indonesia have moderate efficiencies. This might be the result of mixed composition of ownership Islamic banks in these countries. For example, some of them are owned by private such as BCA Syariah (Indonesia) and Am Islamic Bank (Malaysia) while some other are owned by the government BNI Syariah and Bank Islam Malaysia Berhad. This finding is also in-line with (Karas, et al. 2010). The logic is that on the one hand full private owned banks such as in Singapore and the Philippines has the highest efficiency. On the other hand, full government owned bank such as in Thailand has the lowest efficiency score. thus, the composition in between should have moderate efficiency result. 
Indonesia has declining efficiency in comparison to Malaysia. Although in 2011 Indonesia presents higher efficiency compared with Malaysia, Indonesian Islamic banks efficiency is moving downward making it transcended by Malaysian efficiency score in 2016 and forth. This finding can be explained by the study by Barth, Caprio, and Levine (2000). Their study indicates that Indonesia has a very restrictive regulatory system compared with Malaysia. For example, in Indonesia, a bank is prohibited from acquiring any equity investment in a non-financial firm, but in Malaysia, a bank may own equity in any non-financial firm subject to certain conditions (Karim, 2001). It suggests that if the ASEAN market are free to move, Indonesian Islamic banks would be at disadvantages.

There also seems to be a notable difference in the amount of average loan given to customers by Islamic banks in Indonesia and Malaysia, with the average amount of USD1,094,678,000 in Indonesia and USD4,912,464,000 in Malaysia that might indicate why Malaysian Islamic banks are more efficient than Indonesian Islamic banks.

A study done by Alirezaee, Howland, \& Panne (1998) shows that different number of DMUs could results in bias that the higher number of DMU's could lower efficiency score. This might be the cause why Indonesian and Malaysian Islamic banks are less efficient compared to Islamic banks in the Philippines and Brunei. However, this doesn't mean that the results of DEA are meaningless as the score of inefficient units may be interpreted relative to the dominant set.

Although the conditions in each country are different, efficiency comparisons between countries can still be carried out due to the following considerations; firstly, with the AEC, markets with various backgrounds will be integrated, secondly, religious factor doesn't take part in customer decision in choosing Islamic banks (Christanti, et al, 2017), thirdly, rather than religious aspects rationale factors such as free administration cost makes Islamic banks can compete with commercial banks (Christanti, et al, 2017). Under this assumption, Islamic banks in non-muslim countries should be able to attract non-muslim customers. In such ciscumstancr, it is comparable to the attractiveness of Islamic banks in Muslim countries to Muslim customers.

\section{Conclusion}

This study examined evidence concerning the efficiencies of Islamic banks in six ASEAN countries to analyse the technical efficiency under intermediation and production approaches. To measure the efficiency, this study uses the data on the annual financial statements of ASEAN Islamic banks obtained from BankFocus. The results are as follow:

\section{Single Multi-Year}

1. Intermediation Approach

As a country with data available from 2011-2018, Brunei, Indonesia, Malaysia and the Philippines show different trends. Efficiency of Islamic bank in Brunei fluctuated from 2011-2018 and was seen to decline in 2018. In overall observations, Indonesia showed a declining trend. Malaysia Islamic banks enjoyed fluctuations but was seen rising in 2018. The Philippines Islamic bank has not changed its movement significantly from score 1 during 8 years of observation.

2. Production Approach

Brunei experienced almost the same movement for the production approach but its decline in 2018 was not as significant as intermediation. Indonesia has a downward trend in 2011-2018. Malaysia experienced a fluctuation and the score movements in 2018 were seen increasing. Philippines experienced a sharp rise in efficiency in 2015 and there was no major change until 2018.

\section{Intermediation Approach}

\section{Cross-Sectional Analysis}

Results shows that under intermediation approach, Brunei is the country that is most frequent to reach the optimum efficiency, shown in 2015 through 2018. 
Table 18: Rank of Cross- Sectional Results under Intermediation Approach

\begin{tabular}{|c|c|c|c|c|c|c|c|c|}
\hline $\begin{array}{l}\mathrm{R} \\
\mathrm{a} \\
\mathrm{n} \\
\mathrm{k}\end{array}$ & 2011 & 2012 & 2013 & 2014 & 2015 & 2016 & 2017 & 2018 \\
\hline 1 & $\begin{array}{l}\text { Indonesi } \\
\mathrm{a}\end{array}$ & Indonesia & $\begin{array}{l}\text { Philippine } \\
\text { S }\end{array}$ & Singapore & Brunei & Brunei & Brunei & Brunei \\
\hline 2 & Brunei & Malaysia & Singapore & Malaysia & $\begin{array}{l}\text { Philippine } \\
\text { S }\end{array}$ & $\begin{array}{l}\text { Philippine } \\
\text { S }\end{array}$ & $\begin{array}{l}\text { Philippine } \\
\text { S }\end{array}$ & Indonesia \\
\hline 3 & $\begin{array}{l}\text { Malaysi } \\
\mathrm{a}\end{array}$ & Brunei & Thailand & $\begin{array}{l}\text { Philippine } \\
\text { S }\end{array}$ & Singapore & Indonesia & Malaysia & $\begin{array}{l}\text { Philippine } \\
\text { s }\end{array}$ \\
\hline 4 & & & Brunei & Indonesia & Malaysia & Malaysia & Indonesia & Malaysia \\
\hline 5 & & & Malaysia & Brunei & Indonesia & Thailand & Thailand & \\
\hline 6 & & & Indonesia & Thailand & Thailand & & & \\
\hline
\end{tabular}

2. Production Approach

Brunei is also the most frequent in achieving the optimum efficiency under production approach, it happened in five years shown in 2011 through 2012 and 2015 through 2018.

Table 19: Rank of Cross-Sectional Results under Production Approach

\begin{tabular}{|l|l|l|l|l|l|l|l|l|}
\hline $\mathrm{R}$ & 2011 & 2012 & 2013 & 2014 & 2015 & 2016 & 2017 & 2018 \\
$\mathrm{a}$ & & & & & & & & \\
$\mathrm{k}$ & & & & & & & & \\
\hline 1 & Brunei & Brunei & Philippines & Singapore & Brunei & Brunei & Brunei & Brunei \\
\hline 2 & Indonesia & Indonesia & Singapore & Malaysia & Philippines & Philippines & Philippines & Philippines \\
\hline 3 & Malaysia & Malaysia & Thailand & Philippines & Singapore & Indonesia & Indonesia & Malaysia \\
\hline 4 & & & Malaysia & Brunei & Malaysia & Malaysia & Malaysia & Indonesia \\
\hline 5 & & & Indonesia & Indonesia & Indonesia & Thailand & Thailand & \\
\hline 6 & & & Brunei & Thailand & Thailand & & & \\
\hline
\end{tabular}

Different efficiency results in each country might be caused by various internal and external factors such as government regulation, banks size, bank ownership, number of banks, ratio of input and output, and loan given to customers.

\section{REFERENCES}

Adewale, O. L. (2015). Malaysian Islamic Banks' Efficiency: An Intra-Bank Comparative Analysis Of Islamic Windows And Full-Fledged Subsidiaries. International Journal of Business and Society, Vol. 16 No. 1, 1938 .

Alirezaee, M. R., Howland, M., \& Panne, C. V. (1998). Sampling Size and Efficiency Bias in Data Envelopment Analysis. Journal of Applied Mathematics and Decision Sciences, 51-64.

Arrawatia, R., Misra, A., \& Dawar, V. (2014). Bank competition and efficiency: empirical evidence from Indian market. Emerald Insight, 229.

Ascarya, Yumanita, D., Noer A. Achsani, N., \& Gur. (2010). Measuring the Efficiency of Islamic Banks in Indonesia and Malaysia using Parametric and Nonparametric Approaches. Center for Central Banking Education and Studies, Bank Indonesia. 
$\overline{\text { BBC Indonesia. (2014, August 27). Apa yang harus Anda ketahui tentang Masyarakat Ekonomi Asean. Diambil }}$ kembali dari BBC News: https://www.bbc.com/indonesia/berita_indonesia/2014/08/140826_pasar_tenaga_kerja_aec\#orb-banner

Berger, A., \& Humphrey, D. (1997). Efficiency of Financial Institutions: International Survey and Directions for Future Research . Financial Institutions Center.

Bhagavath, V. (2006). Technical Efficiency Measurement by Data Envelopment Analysis: An Application in Transportation. Alliance Journal of Business Research.

Bt Ahmad, N., Mohamad, M. N., \& Sufian, F. (2010). Measuring Islamic banks efficiency: the case of world Islamic banking sectors. Munich Personal RePEc Archive.

Christanti, E. H., Wulandari, D., Narmaditya, B. S., \& Utomo, a. S. (2017). Factors Influencing Customer in Using Islamic Banks Services. International Conference on Economics, Business, and Accounting Studies.

Coelli, T., O'Donnell, C. J., Rao, D. P., \& Battese, G. E. (1998). An Introduction to Efficiency and Productity Analysis. Springer.

Curtis, M.-P. C. (2012, July 3). "Islamic Banking: A Brief Introduction". Diambil kembali dari Oman Law Blog.

Farrell, M. J. (1957). The Measurement of Productive Efficiency. Journal of the Royal Statistical Society, 253-290.

Faturohman, T. (2013). An Examination of the Growth of Islamic Banking in Indonesia from 2003 to 2010. 66.

Favero, C., \& Papi, L. (1995). Technical efficiency and scale efficiency in the Italian banking sector: a non-parametric approach. Applied Economics, 385-395.

Ferreira, C. (2013). Bank market concentration and bank efficiency in the European Union: a panel Granger causality approach. Springer-Verlag Berlin Heidelberg, 369.

Firdaus, \& Hosen. (2013). Efisiensi Bank Umum Syariah Menggunakan Two-Stage Data Envelopment Analysis. JBI, $167-188$.

Hadad, M. D., Hall, M. J., Kenjegalieva, K., Santoso, W., \& Simper, R. (2009). A New Approach to Dealing With Negative Numbers in Efficiency Analysis: An Application to the Indonesian Banking Sector. Dept Economics, Lougborough University.

Hassan, T., Mohamad, S., \& Bader, M. K. (2009). Efficiency of conventional versus Islamic banks: evidence from the Middle Eas. International Journal of Islamic and Middle Eastern Finance and Management, 46-65.

Karas, A., Schoors, K., \& Weill, L. (2010). Are Private Banks more Efficient than Public Banks? Evidence from Russia. Economics of Transition, 209-244.

Karim, M. Z. (2001). Comparative Efficiency Across Select ASEAN Countries. ASEAN Economic Bulletin, 289.

Karimah. (2016). Kajian Efisiensi Bank Umum Syariah. Institut Pertanian Bogor.

Khan, M., \& Bhatti, M. (2008). Islamic banking and finance: on its way to globalization. Managerial Finance, 708725.

Mokhtar, \& Alhabshi. (2008). Efficiency and competition of Islamic banking in Malaysia. Emerald Insight, 28-48. 
Mokhtar, H. A., Abdullah, N., \& Alhabshi, S. (2008). Efficiency and Competition of Islamic Banking in Malaysia. International Journal of Business Society, 22-48.

Pandey, K., \& Satapathy, S. (2014). Use of Data Envelopment Analysis to Measure the Technical Efficiencies of Oil Refineries in India. Journal of Offshore Structure and Technology, 13-31.

Rahman, M. M. (2011). Different Parametric and Non-parametric Approaches to Model the Efficiency of Islamic and Conventional Banks in Bangladesh. International Journal of Business and Management Science, 149.

Research and Markets. (2019, March 20). Global Islamic Finance Markets Report 2019: Islamic Banking is the Largest Sector, Contributing to $71 \%$, or USD 1.72 Trillion. Diambil kembali dari Globe News Wire: https://www.globenewswire.com/news-release/2019/03/20/1758003/0/en/Global-Islamic-Finance-MarketsReport-2019-Islamic-Banking-is-the-Largest-Sector-Contributing-to-71-or-USD-1-72-Trillion.html

Said, A. (2013). Risks and Efficiency in the Islamic Banking Systems: The Case of Selected Islamic Banks in MENA Region. International Journal of Economics and Financial Issues, 66-73.

Sufian, F. (2006). The Efficiency of the Islamic Banking Industry in Malaysia: Foreign vs. Domestic Banks. InternationalAssociation for Islamic Economics, 27-53.

Sufian, Fadzlan, A.M Noor, M., \& Muhamed-Zul. (2008). The Efficiency of Islamic Banks: Empirical Evidence from the MENA and Asian Countries Islamic Banking Sectors. The Middle East Business and Economic Review.

Suzuki, Y., \& Sastrosuwito. (2012). The Impact of Competition on Bank Efficiency: The Evidence from Indonesia. Journal of Business and Management Review.

Tulung, J. E., Saerang, I. S., \& Pandia, S. (2018). The influence of corporate governance on the intellectual capital disclosure: a study on Indonesian private banks. Banks and Bank Systems, 13(4), 61-72.

Turan, H. (2015). The Weighting of Factors Affecting Credit Risk in Banking. Istanbul Conference of Economics and Finance, 49-53.

Y. Altunbas, E.P.M. Gardener , \& P. Molyneux . (2001). Efficiency in European banking. European Economic Review.

Yahya, Y. (2015, September 15). DBS to wind down Islamic banking unit. Diambil kembali dari The Straits Times: https://www.straitstimes.com/business/banking/dbs-to-wind-down-islamic-banking-unit 